\title{
REVIEW
}

\section{Climate change in the uplands: a UK perspective on safeguarding regulatory ecosystem services}

\author{
H. G. Orr ${ }^{1, *}$, R. L. Wilby ${ }^{2}$, M. McKenzie Hedger ${ }^{3}$, I. Brown ${ }^{4}$ \\ ${ }^{1}$ Environment Agency, Environment Centre Wales, Deiniol Rd, Bangor LL57 2UW, UK \\ ${ }^{2}$ Department of Geography, Lancaster University, Lancaster LA1 4YQ, UK \\ ${ }^{3}$ Institute of Development Studies, University of Sussex, Sussex BN1 9RE, UK \\ ${ }^{4}$ Macaulay Institute, Aberdeen AB15 8QH, UK
}

\begin{abstract}
The UK uplands are highly sensitive and significant cultural landscapes that have been created by woodland clearance for agriculture and are at threat from fire, over-grazing, mineral extraction, land drainage, air pollution and recreation. Some of these activities increase upland sensitivity to climate change, contributing to increased flood risk, or soil carbon losses. Many distinct areas of public policy impinge on the uplands, but most have yet to integrate climate change protection within their objectives. Placed within the emerging ecosystems services perspective, policies could be modified to deliver land management services to secure soil carbon stocks, and to protect the goods, services and functions that uplands deliver. There are, therefore, both new opportunities and threats to tackle. The present paper outlines climate sensitivity and change in the uplands; reviews adaptation and mitigation options; and considers available policy, information and management tools. Within an ecosystems framework, emphasis is placed on safeguarding key regulatory services. We offer a research agenda to support adaptation and outline measures that could be developed within existing regulatory frameworks, or signal where policies may need revision. Research priorities include better quantification of carbon fluxes under different soils and land management practices, techniques for up-scaling local interventions to quantify landscape-scale benefits, and the evaluation of adaptive responses in the context of sustainable land use. Potential adaptation strategies include improved spatial planning for land and water, the creation of networked habitats to enable species migration, and practical guidance on appropriate locations for intensification and extensification of land use.
\end{abstract}

KEY WORDS: Climate change $\cdot$ Uplands $\cdot$ Carbon balance $\cdot$ Adaptation $\cdot$ Ecosystem services $\cdot$ Policy

\section{INTRODUCTION}

No formal definition exists for 'uplands' because definitions vary according to local climate, topography and vegetation characteristics. However, elevations $>200 \mathrm{~m}$ above sea level are generally accepted (Stuki et al. 2004), equating to roughly a quarter of the Earth's land surface (Kapos et al. 2000). Climate change presents a special set of challenges for upland regions, as well as new opportunities for their management. The present paper will: (1) summarise evidence of the climate sensitivity and related risks to dominant processes in upland environments, (2) cite examples of mitigation and adaptation opportunities within existing institutional frameworks for UK uplands, (3) identify research needed to support practical adaptation responses and (4) explore where new regulation and governance could address specific risks.

\subsection{Climate sensitivity and change in the uplands}

The potential sensitivity of uplands to anthropogenically driven climatic variation and change have been discussed before (Beniston 2003, Bjornsen Gurung 2005). Although broad principles for adaptation have 
been developed, few adaptation measures have yet been implemented (e.g. Smit et al. 1999, Aerts \& Droogers 2004, Wilby et al. 2005, Smit \& Wandel 2006, EEA 2007). What is lacking is regionally specific information with linked economic and environmental analysis of multiple benefit strategies (including greenhouse gas emissions) within a practical framework of environmental protection and sustainable development.

Uplands are highly heterogeneous meteorologically making them hard to characterise for the present, let alone future, climate (Beniston 2003, Gilles et al. 2006, Pepin \& Kidd 2006). However, evidence of recent climate change comes from observations at high altitude sites across the globe. Winter rainfall and rainfall intensity have increased (e.g. Pepin \& Losleben 2002, Barry 2003, Beniston 2003, Groisman et al. 2005, Malby et al. 2007), and temperatures are increasing more rapidly than at lowland sites, particularly through increases in minimum (nocturnal) temperatures (Bradley et al. 2006). These changes are sufficiently large to melt mountain glaciers (Beniston et al. 1997) and to contribute to sea level rise in the 21st century (Barry 2003, Raper \& Braithwaite 2006).

Upland landscapes provide a wide range of climatesensitive ecosystem goods and services (Millennium Ecosystem Assessment 2005), with consequences for water quantity and quality well beyond their own boundaries (Beniston 2006). Uplands are also unique ecological zones, often providing refuge habitats and nursery areas for species threatened by rising air and water temperatures (Conlan et al. 2007). Species' suitable climate space is already changing (Hickling et al. 2006), placing some vulnerable habitats and species at risk (e.g. Walmsley et al. 2007). Upland sensitivity to environmental change is widely recognised, as is their influence on downstream ecosystems and economies (Burt 2001, Werritty 2002). Hence, uplands could be regarded as sentinels of regional climate change that may pre-herald impacts elsewhere (Beniston et al. 1997). This review focuses in particular on safeguarding the environmental regulatory services that uplands provide, although by following an ecosystems approach it inevitably also includes supporting, provisioning, and cultural services within the larger-scale framework (Millennium Ecosystem Assessment 2005).

Observational evidence from all continents and most oceans shows that many natural systems are being affected by regional climate changes, particularly temperature increases (IPCC 2007). Change will continue over the next $50 \mathrm{yr}$ (Christensen et al. 2007), so it is important to understand impacts and to implement timely adaptation responses. Developing improved predictive tools such as catchmentscale climate change scenarios and impact models represents an important step towards planning adaptive land management. This is because the hydrology, geomorphology, soils, ecosystems and socio-economic contexts of upland areas imply a characteristic set of location-specific, climate-driven risks (Table 1).

\subsection{Special issues in UK uplands}

The UK uplands are highly valued culturally. They are important assets for rural employment, tourism, recreation and contain most of the large-scale protected landscapes in the UK. They are mainly in private ownership, but have been protected for over $50 \mathrm{yr}$ for their natural beauty, landscape and nature conservation characteristics. By global standards, the UK uplands are small in scale, with distinct land tenure and management issues, but, in common with others, they are remoter areas, with low population densities and land uses dominated by pastoral agriculture and forestry. Uplands are important for water supply $(70 \%$ of UK resource) and biodiversity, and there have been long-running tensions arising from conflicting use of these areas for agriculture, forestry and conservation.

UK uplands are classified informally as land above the line of enclosure. This boundary is typically 200 to

Table 1. Climate-driven processes and associated impacts in the uplands

\begin{tabular}{|c|c|c|}
\hline & Drivers & Impacts \\
\hline $\begin{array}{l}\text { Physical } \\
\text { component }\end{array}$ & $\begin{array}{l}\text { Changes to: duration, magnitude, } \\
\text { frequency, suddenness }\end{array}$ & $\begin{array}{l}\text { Changes to: resilience, } \\
\text { vulnerability, flexibility, scale }\end{array}$ \\
\hline Climate & $\begin{array}{l}\text { Temperature, precipitation, } \\
\text { wind, radiation }\end{array}$ & $\begin{array}{l}\text { Snow melt/frost-free period, } \\
\text { flooding, drought, soil } \\
\text { moisture }\end{array}$ \\
\hline Hydrology & $\begin{array}{l}\text { Total runoff, flood, drought. } \\
\text { Seasonal variation in runoff }\end{array}$ & $\begin{array}{l}\text { Water quality and quantity } \\
\text { Increased flood exposure } \\
\text { Water supply reliability } \\
\text { Wetland sustainability }\end{array}$ \\
\hline $\begin{array}{l}\text { Geomor- } \\
\text { phology }\end{array}$ & $\begin{array}{l}\text { Weathering, erosion, landslides, } \\
\text { debris flows, channel activity. } \\
\text { Mobilisation of sediment }\end{array}$ & $\begin{array}{l}\text { Sediment supply, transport } \\
\text { Source channel connectivity } \\
\text { Mobilisation of pollutants }\end{array}$ \\
\hline Soils & $\begin{array}{l}\text { Fertility, nutrient cycling } \\
\text { Biophysical processes } \\
\text { Erosion }\end{array}$ & $\begin{array}{l}\text { Increased water pollution, } \\
\text { Loss of soil function } \\
\text { Loss of carbon }\end{array}$ \\
\hline Ecology & $\begin{array}{l}\text { Species migration } \\
\text { Invasive species, extinction } \\
\text { Ecological processes } \\
\text { Primary productivity }\end{array}$ & $\begin{array}{l}\text { Habitat loss and change, } \\
\text { Loss of ecosystem services } \\
\text { (e.g. buffering, filtering) }\end{array}$ \\
\hline
\end{tabular}


$300 \mathrm{~m}$ above sea level, but has varied historically due to fluctuating rural population pressure and economic returns from marginal agricultural land. In addition, effective upland management requires recognition of all land uses within the landscape, from valley to hillsides to summits. Nevertheless, if a broad representation of upland climate and vegetation 'types' is considered, then the uplands can be regarded as extending from the highest ground in SW England to sea level in cooler NW Scotland (Ratcliffe \& Thompson 1988, Averis et al. 2004). Fig. 1 shows the uplands considered for the purpose of this review.

Many UK uplands are now exploited less for natural resources than for scenic amenity, leisure and tourism. A suite of national designations has emerged from the complex administrative framework (with control devolved to agencies in England, Wales, Scotland and Northern Ireland) and requirements of European Union (EU) directives. Hence, areas of high landscape quality, which are mainly in the uplands, are designated as National Parks, Areas of Outstanding Natural Beauty (AONB), or National Scenic Areas (NSAs) in Scotland. Similarly, areas of high biodiversity or geological value are designated as National Nature Reserves or Sites of Special Scientific Interest (SSSI), and some are incorporated in the European Natura 2000 network. Within National Parks, many residents

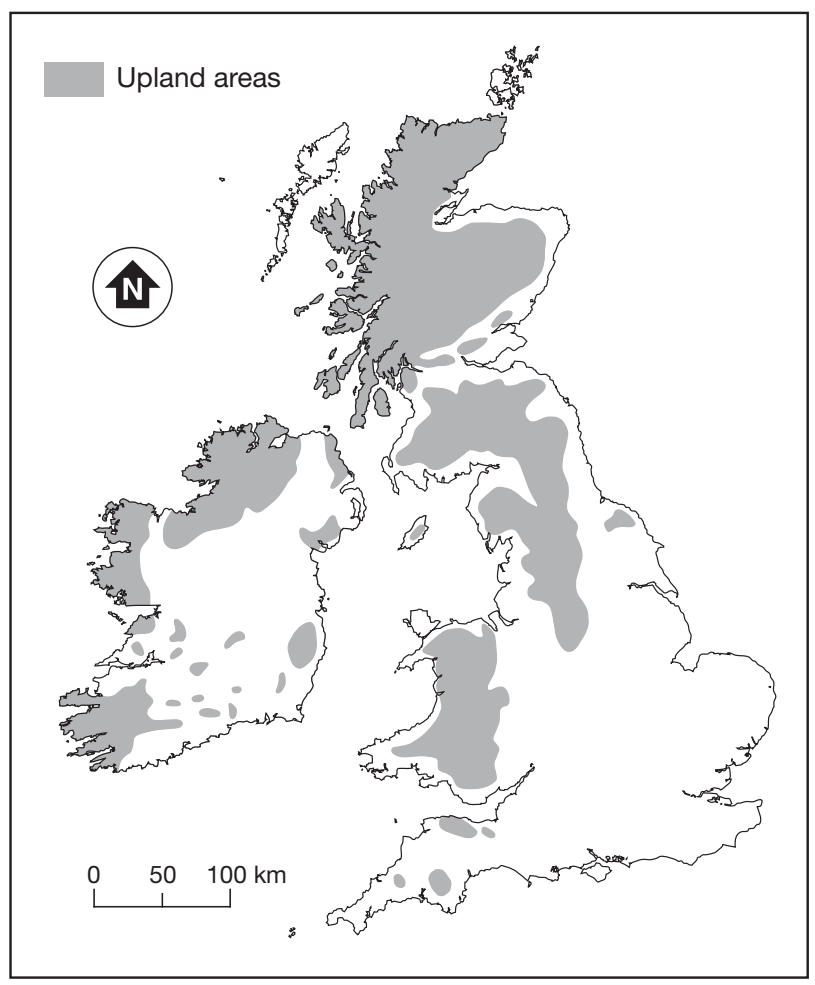

Fig. 1. Uplands of the British Isles (modified from Averis et al. 2004) work on land-related employment, although agriculture now contributes $<1 \%$ of the UK economy (Curry Report 2002), but, despite fewer people employed in farming, National Parks typically have higher rates of employment and in-migration compared with other rural areas (Park et al. 2004).

Uplands have a very long history of native woodland removal and agricultural intensification leading to the loss of semi-natural habitats (e.g. Simmons 2003). Afforestation with conifer plantations has not replaced the area of native woodland lost. Heather moorland has decreased by about $23 \%$ since the 1940s, having been replaced by new conifer plantations or converted to grazing land. Recent population growth and economic development have added new pressures, particularly through greater demands on infrastructure and on the landscape due to tourism. Uplands are also cultural landscapes shaped in the past, present and future by multiple land uses such as farming and grouse management (Defra 2006, Holden et al. 2007). Uplands are increasingly being viewed in terms of the ecosystem services they provide, with new ways of seeing and capturing value in biodiversity. However, the full benefits and costs of upland goods and services may not be reflected in the local economy. For example, headwaters draining unmodified peat moorlands may yield cost savings for downstream water users compared to modified moorlands; modifications include draining, burning and heavy grazing. In short, upland economies in the UK remain highly dependent on primary sectors (e.g. agriculture, forestry, sporting estates) together with tourism, and water resource management (water supply and hydro-electric power), all of which are exposed sectors in terms of climate change risks (HM Government 2006). This implies that adaptation via land management and spatial planning will require upland farmers and land managers to both recognise, and potentially be rewarded for, the less tangible products and wider public benefits that they provide (Defra 2006, Piper et al. 2006). We may not be able to rely on plentiful, clean water from the uplands indefinitely at such a very low cost (Millennium Ecosystem Assessment 2005).

The cool-wet climate of UK uplands has a strong influence on natural processes and land use (Manley 1951). In the future, the UK climate is projected to have wetter milder winters, hotter drier summers and a greater frequency of extreme precipitation events in all seasons (Hulme et al. 2002). Some of these patterns are beginning to emerge from a background of considerable natural variability (e.g. Osborn \& Hulme 2002, Karoly \& Stott 2006). For example, winter precipitation has shown large changes - in parts of western Scotland totals have increased by 60 to $100 \%$ since 1960 (Barnett et al. 2006). There is evidence of more 
rapid warming (Holden \& Adamson 2002) and more marked precipitation changes in uplands (Malby et al. 2007). Winter rainfall intensity has increased over high ground (Fowler \& Kilsby 2007), and rain shadows may have weakened leading to greater risk of local flooding over recent decades (Malby et al. 2007). Intense orographic rainfall events are prominent amongst the dozen occasions on which precipitation totals exceeding $200 \mathrm{~mm}$ in $24 \mathrm{~h}$ have been reliably recorded in the British Isles (Burt 2005). Although there are too few such events for trend analysis, overall, mean winter rainfall and river flows have increased in western parts of upland Britain since the 1960s (Wade et al. 2005, Dixon et al. 2006, SEPA 2006, Wilby 2006). There is also tentative evidence of long-term changes in snow cover and persistence in UK uplands (e.g. Harrison et al. 2001, Watson et al. 2004, Johnson 2005). However, the attribution of rainfall-runoff trends to climate change is not yet possible at the scale of the UK, not least because of the confounding effect of multidecadal variability linked to the North Atlantic Oscillation (Wilby 2006).

The climate change mitigation agenda could place further demands on some upland areas. Recent research has focused on the contribution made by upland environments to the global carbon balance (e.g. Worrall et al. 2004). In the UK, the greatest soil carbon density is found beneath woodland and seminatural land uses (Bradley et al. 2005). Peatland and upland soils contain at least $50 \%$ of the soil carbon in Britain (Milne \& Brown 1997). Organic soils in Scotland and Wales contain approximately $3000 \mathrm{Mt} \mathrm{C} \mathrm{(Scottish}$ Executive 2007). In comparison, the UK contributes $150 \mathrm{Mt} \mathrm{C} \mathrm{yr}^{-1}$ to total global carbon emissions of $6000 \mathrm{Mt}$ C. Historically these soils have been regarded as carbon sinks, but there is growing concern about a possible long-term transition to a carbon source, driven by a combination of climate change, over-grazing, fire and land drainage (e.g. Worrall et al. 2007). Furthermore, the use of uplands for forestry and renewable energy (notably wind energy) has been given prominence in the policy agenda, sometimes to the detriment of adaptation.

\section{VULNERABILITY OF UK UPLANDS}

Uplands have specific vulnerabilities described in the following sections on hydrology, geomorphology, soils, ecology and land use. Evidence of recent and projected environmental change is considered alongside associated risks and opportunities. Gaps in knowledge are identified with particular focus on where these could constrain mitigation and adaptation options.

\subsection{Hydrology and hydrochemistry}

Climate-driven changes in hydrological regimes directly impact water resource management, ecosystem health, flood risk and hazard management (Fowler \& Kilsby 2003, Jasper et al. 2004). Climate projections are particularly problematic for upland river catchments because of the complex terrain and climate feedbacks (Gilles et al. 2006, Christensen et al. 2007). In addition, runoff from upland environments has a very high range of natural variability over daily and interannual timescales, making climate change detection in discharge records particularly challenging for these areas (Wilby 2006).

Although national analyses of runoff do not show sustained trends in UK river flows (Robson 2002, Hannaford \& Marsh 2006, Wilby et al. 2007), regional changes in flood frequency, flow duration and flow variability have been observed over recent decades, such as a shift to greater winter flows in western Britain (Black \& Burns 2002, Wade et al. 2005, Orr \& Carling 2006, SEPA 2006, Wade \& Vidal 2006). This is associated with trends in the North Atlantic Oscillation over the same period, resulting in a greater prevalence of westerly airflows in winter and increased precipitation on western upslopes (Barker et al. 2004). However, lack of systematic quantitative data on land cover changes makes the separation of land use and climate signals in runoff trends very difficult for most UK catchments (O'Connell et al. 2004).

Costs from future flooding in the UK are expected to rise by between 2 and 20 times the present values by 2080 (Evans et al. 2004). High flows, those exceeded $<5 \%$ of the time are projected to increase in magnitude by up to $25 \%$, particularly at high elevation catchments, providing an increased risk of flooding during winter months (Fowler \& Kilsby 2007). Rivers fed by upland systems are expected to mobilise greater sediment, potentially exacerbating flood levels (e.g. Lane et al. 2007) and channel migration (Werritty \& Leys 2001). Ongoing work is examining regional variations in UK flood risk under climate change, taking into account the influence of underlying catchment properties and changes in snowmelt regime (Crooks 2006).

Increasing drought frequency driven by lower summer rainfall could impact adversely on upland ecosystems and water supply. Indeed, significant changes in low flows in southern England are expected as early as the 2020s (Arnell 2003, Wade et al. 2005, Fowler \& Kilsby 2007). Small single-season upland reservoirs of NW England could be particularly vulnerable to future droughts (Wade \& Vidal 2006), whereas larger reservoirs that can contain more winter storage may be less sensitive (Fowler \& Kilsby 2007). Summer rainfall scenarios are even less certain for northern Britain than 
southern areas, with considerable variation between climate models, meaning that assessment of adaptation options is rather less advanced (e.g. Werritty 2002).

There are a large number of indirect chemical impacts associated with hydrological change in the uplands. For example, subtle changes in acid deposition and activation of ephemeral hydrological pathways during heavy rainfall are expected to delay the recovery of acidified catchments (Wilby 1996, Evans et al. 2001, Monteith \& Evans 2005). There are also high levels of nitrogen deposition in upland areas and potential for leaching nitrate to freshwaters (Curtis et al. 2005, Helliwell et al. 2007). In particular, high altitude catchments dominated by mineral rather than peat soils may be more susceptible to nitrate leaching (Helliwell et al. 2007). There may be selective contamination by other anthropogenically derived pollutants, such as mercury and lead, related to past mining activity (Battarbee et al. 2005). Dissolved organic carbon (DOC) is also increasing and may be related to climate change. Repeated droughts may result in long-term loss of carbon from organic-rich soils (Sowerby et al. 2008). In addition, drought conditions increase nitrogen mineralisation and sulphur oxidation, leading to the release of nitrate and sulphate into surface waters (Miller et al. 2001). In lowlands, post-drought 'flushing' by intense winter rainfall enhances nutrient delivery (Whitehead et al. 2006). It is unclear how important this mechanism could become in the uplands, where nutrient levels are generally low, but receiving waters may be particularly sensitive to even small increased inputs. Rising water temperatures further increase the rate of dissolution and precipitation reactions during low flows (Langan et al. 2001).

As noted above, uplands can be important for seasonal water storage in the form of snow and ice, or as soil moisture in thick peat deposits. Predicted reductions in snow cover leading to earlier runoff, lower soil moisture and drier vegetation in spring increase the risk of fire and droughts (McEvoy et al. 2006). A number of land management practices with detrimental environmental impacts may be exacerbated by climate change. For example, high-density grazing and poor forestry practices can modify soil structure and vegetation cover in ways that increase the rate and volume of runoff (Stott \& Mount 2004, Orr \& Carling 2006). Conversely, practices that promote localised soil water retention include increasing soil organic matter and reducing compaction (Bragg 2002, Tollan 2002, Carroll et al. 2004, Ellis et al. 2006). However, to what extent these can influence flood and drought reduction at river catchment scales is uncertain; the local response may be shown, but regional outcomes are less clear and require further research (Wheater 2002, O'Connell et al. 2004).
Demand for upland water resources is expected to increase under climate change as there are moves towards greater use of renewable sources of energy (hydro-electric power) and water generally. Whilst upland areas have large reservoirs for water supply, they also contain numerous small, often private, supplies that may be particularly vulnerable to droughts. Coupled to this are the large number of private sewerage treatments that may have an increasing impact on water quality through reduced dilution and, hence, indirect effects on upland ecosystems.

\subsection{Geomorphology}

Climate is the major driver of landform evolution in tectonically inactive areas; thus, climate change could modify geomorphic processes and disturb landscape stability. For example, more intense precipitation could accelerate landscape evolution through mass movements, debris flows, soil erosion, transport of hillslopederived sediments, and channel change. Although it is difficult to monitor trends in the frequency of extreme events in remote places, increased geomorphic activity is expected with a shift in climate regime (Jones 1993a,b, Rumsby \& Macklin 1994, Macklin et al. 2005, Chiverrell et al. 2007). However, the response to increased rainfall can be complex as sediment derived in headwaters is transferred through river catchments via intermediate sediment stores and downstream propagation of landform instability (Dadson \& Church 2005).

Uplands are amongst the most geomorphologically active areas in the UK, because slope-channel connectivity is high and there are significant areas of bare ground. Furthermore, land-use pressures are presently causing vegetation removal, which is expanding the areas of eroded topsoil and potentially increasing the risk of accelerated soil loss under climate change. For example, the area of eroded topsoil in a $350 \mathrm{~km}^{2}$ catchment of the English Lake District increased from $4 \%$ in the 1970 s and 1980 s to $8 \%$ in 2000 (H. Orr unpubl. data). Erosion of topsoil represents a carbon loss and has importance for upland conservation status by adversely affecting sensitive ecosystems, particularly upland water bodies. Some land-use changes increase landscape sensitivity (Thomas 2001); for example, periods of active hillside gullying in NW England are only evident in the later part of the Holocene following significant woodland clearance and introduction of sheep (Chiverrell et al. 2007).

Steep upland channels are capable of delivering very large amounts of coarse sediment during floods, which can accumulate behind obstacles and impede flows (Johnson \& Warburton 2002, Burt 2005, Golding 
et al. 2005). Traditional management strategies include gravel traps, but these are often overtopped and represent unwelcome habitat modification for some species such as crayfish. Alternative measures include reducing hillslope-channel coupling through woodland buffer strips on steep upland tributaries. Recent modelling studies suggest that up to $80 \%$ reduction in sediment delivery can be realised by these methods (Lane et al. 2008). An important source of fine sediment in river catchments is often riverbank erosion or, indirectly, channel engineering (e.g. Hatfield \& Maher 2008). Increased stream power and changing flood frequency could lead to more rapid and extensive bank erosion. However, careful riparian management, such as stock exclusion, helps reduce sediment losses from sites that are not experiencing very active planform change through meander migration.

Uplands are also subject to hazards such as landslides, debris flows, bog bursts and sediment mobilisation from floodplains (Jones \& Lee 1994, Warburton et al. 2004). These events pose severe risks to local communities and infrastructure, and trigger sediment accumulation/bed morphology changes downstream (Johnson \& Warburton 2002). Sediment-related problems often occur in rivers that have lost natural deposition areas as a result of embankments, revetments and artificial channelisation. This limits space for channel adjustment following large floods and can lead to sediment deposition in undesirable locations, exacerbating conditions for river management (e.g. Sear et al. 1995). Recent policy initiatives are beginning to acknowledge these issues and develop schemes to 'make space' for water and surplus sediment by restoring floodplains and multiple river channels (Defra 2005a).

\subsection{Soils}

Soils provide a wide range of ecosystem goods and services and act as the buffer between atmospheric and aquatic processes. Recent warming and changes in rainfall patterns may help explain recently altered biogeochemical processes in upland soils with potentially profound effects. Since the industrial revolution, uplands in the UK have been subject to high levels of atmospheric deposition of pollutants, leading to acidification and, in recent decades, to the export of terrestrial carbon. The carbon loss from the terrestrial biosphere has been manifested, in part, by increased DOC in stream water (Freeman et al. 2001a, Worrall \& Burt 2004, Worrall et al. 2004) and by carbon reduction in soils (Bellamy et al. 2005). Northern upland peatland systems have become the focus of attention because they are major carbon sinks and major sources of water supply. Even a relatively small imbalance between production and decay of carbon in these systems can cause peatlands to shift from carbon sinks to sources (cf. Laiho 2006). This has raised concern that these losses may constitute a positive feedback to global warming by increasing terrestrial carbon release (Cox et al. 2000).

Peat and peaty soils cover only $14 \%$ of the UK, yet contain more than half of the soil carbon (Milne \& Brown 1997, Dawson \& Smith 2008). Much of this soil carbon is in deep Scottish blanket peat (2735 Mt C; Scottish Executive 2007). In England and Wales stagnogleys, brown earth and raw peat soils contain most carbon, predominantly in the uplands (Milne \& Brown 1997, Dawson \& Smith 2008).

The distribution of observed increases in DOC across the Northern Hemisphere and for a variety of land uses (Driscoll et al. 2003, Hejzlar et al. 2003) indicates a large-scale driving mechanism, currently the subject of intense research efforts and speculation (cf. Roulet \& Moore 2006). The dominant competing hypotheses are recovery from acidification (Evans \& Monteith 2001, Evans et al. 2006, Monteith et al. 2007), elevated temperature and $\mathrm{CO}_{2}$ effects on soil primary production and rates of organic matter decomposition (Freeman et al. 2001b, 2004, Worrall et al. 2006) and climate-driven changes in hydrological processes and drought (Sowerby et al. 2008). The first is supported by correlation and metadata analysis, but a full explanation of the process is not yet available; the latter 2 are supported by field and laboratory studies, but at small scales.

Local conditions regulate DOC flux so the trend is not always upwards, as is presently occurring in SW England (although these areas have been less impacted by acidification). Some soil carbon losses are explained by agricultural extension over the last 20 to 30 yr, particularly land drainage leading to soil erosion (Evans \& Monteith 2001, Janssens et al. 2003), increased productivity in crop yields and less use of animal manure (Smith et al. 2007b). Direct temperature rises explain $12 \%$ of the DOC increase in an intact upland peat bog in the Pennines (northern England); repeated droughts and an enzyme latch mechanism may account for the remainder (Worrall et al. 2006). This is because enzymes are switched on by water table drawdown, but not switched off after water table recovery, effectively increasing peat decay and carbon loss (Freeman et al. 2001b, Wallage et al. 2006, Worrall et al. 2006).

Over longer time scales, persistent lowering of peatland water tables as a result of drought does not always result in a reduced carbon store (Laiho 2006). The carbon flux depends on vegetation composition, organic matter input and substrate availability to enzymes 
(Davidson \& Janssens 2006, Laiho 2006). Older peat formations can only decay, but decomposition and carbon release from newer peat layers may be offset by rates of new peat growth (Worrall \& Burt 2005). Furthermore, fluvial export of carbon as undissolved particulate organic carbon (POC) is secondary to losses through gaseous exchange in eroding peatlands and at least equivalent to the net gaseous flux from intact peatlands (Worrall et al. 2003, Evans et al. 2006b). The fate of POC is not well understood except that much may be deposited within fluvial environments either at the base of slopes or on floodplains. Questions surround how readily POC is oxidised and released as carbon to the atmosphere.

It is clear that many upland peatlands, particularly in England and Wales, are 'damaged' to some extent by land-use practices and atmospheric pollution. Restoration of these areas would help to protect existing carbon stores and wider ecosystem functions. For example, the organic content of soils is an important determinant of water-holding capacity and propensity to erosion (Bragg \& Tallis 2001). More research is needed on carbon flux mechanisms at plot to landscape scales (e.g. Janzen 2006, Sowerby et al. 2008) and on the sensitivity of different soil types to climate change (Laiho 2006). Although the main pathways of carbon in its various forms are broadly understood, the relative importance of some pathways is less clear (Fig. 2). As noted previously, the management of eroding peatlands is best achieved by measures that reduce connectivity between slope and channel, thus reducing sediment loss (Evans et al. 2006b).

Drier summers could increase the risk of fires in upland peatlands (see also Defra 2004), with greater consequences for soil carbon loss than biotic responses (Davidson \& Janssens 2006). A study of moorland fire frequency in the Pennines showed a high incidence during the hot dry summer of 1976 and dry spring of 2003, and the greatest frequency of fires tended to be on eroded bare peat (McMorrow et al. 2006). Water treatment plants downstream of blanket bogs can incur increased costs when DOC emissions rise following upland fires (Worrall \& Burt 2005). A further complicating factor is that some moorland is regularly burnt as part of a deliberate management strategy to encourage new vegetation growth for game birds.

Although some water bodies are presently showing recovery from acidification following reduced sulphur emissions (Monteith \& Evans 2005, Wright et al. 2005), soils represent significant stores of pollutants that may be remobilised under climate change, thereby delaying long-term recovery (Battarbee et al. 2005). Furthermore, high nitrogen deposition has increased substrate fertility and has been linked to a shift in species composition in upland vegetation (Smart et al. 2003).

Agricultural soils are, in some (mainly lowland) catchments, a major source of phosphorus contamination of surface waters (Defra 2000, McDowell et al. 2001) and cause of freshwater eutrophication (Vollenweider 1968, Sharpley 2000). It is generally assumed that phosphorus delivery to upland waters is low. However, given the greater sensitivity of nutrient-poor upland rivers and lakes, even small additions from diffuse sources can result in nutrient enrichment and loss of some species. Unfortunately, there has been limited research to date on phosphorus budgets and export from upland soils, or on potential implications of changes in land use.

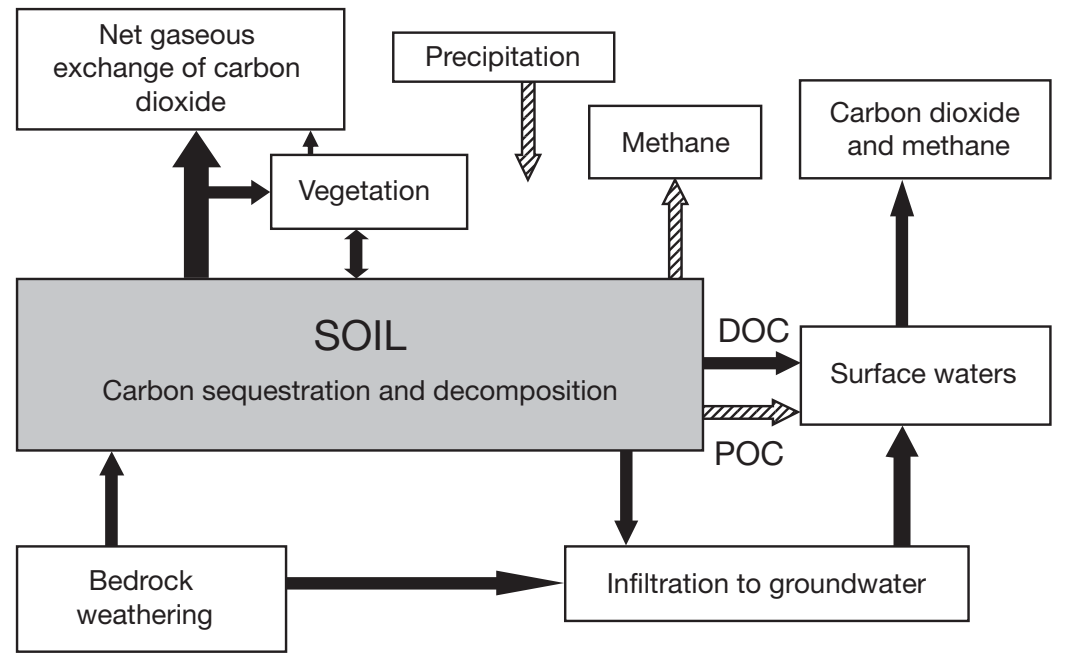

Fig. 2. Simplified carbon flux pathways from soil (after Worrall et al. 2003). Hatched arrows represent fluxes about which we have uncertain knowledge

\subsection{Ecology}

Climate influences the distribution of species and fundamental ecological processes such as photosynthetic capacity and trophic interactions. Largescale meta-analyses indicate a consistent signal among species and taxa expressed as alterations to plant and animal populations across the globe (Parmesan \& Yohe 2003, Root et al. 2003). Range shifts polewards and upwards (Klanderud \& Birks 2003, Hickling et al. 2006) are consistent with palaeoecological studies showing that the key response by species to climate change is range adjustment (Huntley \& Webb 1989). However, ecological adjustment over the last 20000 yr was not 
faced with such rapid rates of temperature change as those predicted for the next $100 \mathrm{yr}$, nor with the degree of habitat fragmentation and modification of postindustrial times (Root \& Schneider 2006). Climate changes may thus be too rapid for some species to migrate or adapt to a changing food supply, so extinctions and a loss of biodiversity are likely (Thomas et al. 2004, Hannah et al. 2005, Malcolm et al. 2006).

Recent changes in UK species' phenology have been reported (Collinson \& Sparks 2003, Sparks \& Collinson 2006). Upland habitats are already under pressure from grazing livestock and atmospheric pollution and may be particularly sensitive to climate change impacts (Hossell et al. 2000). In addition, genetic diversity, and hence the adaptive capacity of some Arcticalpine plant populations, such as the Snowdon lily, is low (Jones \& Gliddon 1999). Reduction in snow cover affects snow buntings, which rely on insects in snow patches for food, and also some bryophyte species, which require snow as insulation against low winter temperature or as a source of moisture in spring (Hill et al. 1999).

Because key bioclimatic variables have a dominant influence, either directly as constraints or more usually indirectly by controlling food supply and breeding success, it is possible to classify and map bioclimatic zones. Bioclimate envelope modelling has been used to predict potential species' responses across Britain and Ireland (Berry et al. 2003, Dockerty et al. 2003, Araújo et al. 2005). This methodology clearly shows that the areas of greatest bioclimatic heterogeneity are in the uplands, corresponding to a wide variety of habitats (Hossell et al. 2003). In addition to projected range changes, these models show potential loss of important montane species due to reductions in suitable climate space (e.g. Black grouse, Capercaille and Arctic-alpine plants such as Norwegian mugwort and twinflower) (Walmsley et al. 2007). Some rare species have 'nowhere to go', such as Snowdon lily, northern dart and icy rock moss, simply because they are already in isolated positions at their limit, and the possibility of more suitable, northerly/higher altitude locations does not exist (Hossell et al. 2000). Few studies report changes in ecosystem processes as a result of species loss and movement, although attention has been focussed on indicators of ecosystem response, notably keystone or focal species (e.g. Simberloff 1998). Similarly, questions remain about the potential for species to colonise new niches and the impact of invasive alien species.

Uplands include many 'open', semi-natural habitats found above the upper limits of agricultural enclosures, such as heaths, bogs, rough grasslands, and rocky habitats on screes, ledges and mountain slopes. These habitats have important interfaces with native woodlands and freshwaters, and support a wide range of species. Climate change may affect disturbance regimes due to fire, pest outbreaks and severe storms. These influence species adaptation rates or succession processes, favouring some less-specialist invasive species so novel ecosystems should be expected (Hobbs et al. 2006). In addition, changes in the upland climate may result in asynchrony of breeding cycles and availability of food, as already noted for important bird species (Moss et al. 2001, Pearce-Higgins et al. 2005, Beale et al. 2006). Change is inevitable and may be non-linear; therefore, the challenge is to determine how to maintain essential and/or desired ecosystem functions (Hulme 2005). Change may also be sudden as loss of ecosystem resilience usually paves the way to catastrophic change (Scheffer et al. 2001).

Understanding climate-driven changes in freshwaters is particularly complex because ecological processes are affected by local meteorological, hydrological and nutrient regimes, as well as by indirect terrestrial impacts (Conlan et al. 2005). Upland freshwater flow regimes are often more highly variable, making detection of individual pressures more difficult, and, in general, they are less well served by monitoring data. Species population data are generally spatially limited and of short duration (e.g. Monk et al. 2006), except for high-profile species such as salmon. These data show declining upland salmon populations linked to climatic changes, affecting ability to grow and survival during time in the sea, as well as freshwater pollution (including acidification), habitat degradation, overexploitation and excess predation (e.g. Mills 2003, Davidson \& Hazelwood 2005). Climate signals have also been found in the physical, chemical and biological characteristics of lakes (George et al. 2004), and in the abundance and community composition of invertebrate populations (Durance \& Ormerod 2007; Fig. 3).

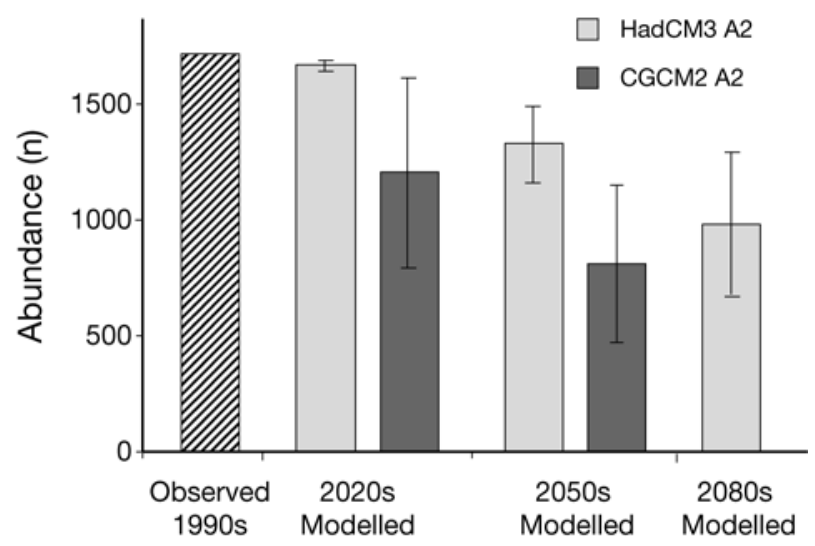

Fig. 3. Changes in abundance of freshwater invertebrates for upland Welsh streams using 2 General Circulation Models (GCMs) and 1 medium-high emission scenario (A2, UKCIP02) (adapted from Conlan et al. 2007). Error bars: \pm SE 
Higher temperatures and reduced flows/lake volumes could increase eutrophication and exacerbate the effects of acid pollution (Schindler 2001). Nonetheless, distinguishing the range of natural variability in freshwater populations from human-induced trajectories of change driven by climate is of critical importance to the delivery of 'good ecological status' under the EU Water Framework and Habitats Directives (Wilby et al. 2006). Homogeneous records of specieslevel freshwater invertebrate data have improved understanding of ecological responses to changes in flow regime, but such data are relatively rare (Jackson \& Füreder 2006, Monk et al. 2006). Monitoring systems will need to be reviewed as species adapt to new regional climatic gradients, flow regimes and water body status (Monk et al. 2006).

Hydrological process modelling suggests that UK upland freshwater ecosystems are particularly sensitive habitats (Conlan et al. 2007, Durance \& Ormerod 2007). Climate change impacts have been explored in terms of fish growth rates (Davidson \& Hazelwood 2005), loss of fish habitat due to rising water temperatures (Rahel et al. 1996), low flows (Conlan et al. 2007) and changing hydromorphology (Orr \& Walsh 2006). It is also recognised that upland populations may be affected by changes in other (remote) habitats as well as in situ conditions. For example, rising ocean temperatures affect salmonid survival (Davidson \& Hazelwood 2005), and upland stream temperature changes at critical points in the juvenile salmon life cycle have been associated with earlier out-migration (Langan et al. 2001). Questions remain about the relative importance of climate stressors compared with other pressures such as habitat degradation and diffuse pollution.

\subsection{Land-use change}

The UK uplands tend to be relatively sparsely populated, except where there is a legacy or ongoing use of natural resources, or where landscapes of high scenic value are accessed. Land use is therefore strongly related to socio-economic drivers, especially in agriculture and forestry, but also in some areas through grouse and deer management. Traditional use of land to provide food, fibre, wood, or other fuels is also increasingly combined with conservation or cultural landscape functions (recreational, aesthetic, or educational) that support a growing tourism industry. However, land use is also constrained by biophysical limitations, notably from the prevailing climate. By influencing land-use patterns, a changing climate can therefore indirectly affect hydrological, ecological, soil and geomorphological functions. As a consequence, exploration of land-use scenarios in conjunction with climate scenarios can become an important component when considering upland vulnerability and adaptation options (Audsley et al. 2006). Land-use scenarios are conventionally developed from generic socio-economic scenarios, such as the IPCC (Intergovernmental Panel on Climate Change) special report on emissions scenarios (IPCC 2000, Rounsevell et al. 2005). Some modelling environments can integrate different landuse scenarios (e.g. afforestation or new crops), and these can be used to explore sensitivities to future change (e.g. Holman et al. 2005); these may be particularly useful when developing catchment-based programmes of measures under the Water Framework Directive (WFD).

Both UK and European uplands are expected to be affected by recent reforms of the Common Agricultural Policy (CAP), which may lead to reductions in overgrazing, but in the long term there is large uncertainty. The UK foot and mouth crisis in 2001 has had an impact on the numbers of grazing animals in the uplands. For example, sheep in the largely upland county of Cumbria were at 2.6 million in 2000, 1.2 million were then culled in 2001, but numbers had returned to 2 million by 2006 ; this is still a high grazing intensity. Approximately $8 \%$ of the total UK sheep flock were culled (Defra 2007a). Market developments are likely to be a more significant driver of agricultural land-use change than climate variation (Holman et al. 2005, Rounsevell et al. 2005), although water stress in southern Europe may lead to indirect climate advantages for agriculture in the UK (e.g. Edwards-Jones et al. 2007). Amelioration of the upland climate could provide new opportunities in some areas that are currently 'marginal', especially if they are close to urban markets, and can thus reduce 'food miles'. Similarly, the growth of 'carbon offsetting' schemes is encouraging further planting of forests in British uplands, and, in Scotland, there is a strategic aim to increase forestry coverage to $25 \%$ of the country. Conversely, if market opportunities decline, land 'abandonment' could become an increasingly realistic scenario.

Climate change is expected to stimulate upland tourism and hence the need for investment in the protection of vulnerable sites (McEvoy et al. 2006), although the potential for winter sports has notably declined (Harrison et al. 2001). Visitor access to 'unimproved' land has also been formalised as a legal right. Recent growth in the economic importance of tourism has not necessarily translated into economic gains for land managers or facilitated the achievement of conservation objectives. Indeed, declining employment in agriculture and natural resource management could constrain future conservation potential (Scottish Agricultural College 2002, English Nature 2003, HM Government 2006). 
To alleviate these pressures, many UK uplands have stakeholder partnerships linked with planning authorities for National Parks or AONBs. Many of the partnerships are developing innovative schemes promoting long-term strategic planning for the future. However, large areas of uplands fall outside current statutory designations (including NSAs in Scotland) and are therefore neglected, sometimes because they are deemed to have insufficient biodiversity value or landscape quality, despite the presence of significant seminatural habitat, organic soils and services to downstream areas. Furthermore, the stakeholder model for partnerships often excludes individuals or small communities who do not have a specific well-defined interest, aside from living or working in the area.

New economic niches can also drive land-use change. For instance, European policy promotes the use of biomass in order to achieve a doubling of renewable energy supply across the EU, providing wood fuel energy as well as carbon sequestration. The Community Biomass Action Plan (European Commission 2005) aims to increase total biomass production by 2010 to $>40 \%$ of 2001 levels. This is likely to drive significant land-use change (e.g. Andersen et al. 2005) and possible displacement of pastoral agricultural activities, as areas most likely to be affected are marginal zones fringing the uplands where biomass could prove more economic than conventional agriculture. Uplands therefore have an emerging economic role in carbon sequestration and control of emissions through soil, vegetation and landscape management. Options include: (1) preserving healthy or restoring degraded peatlands, (2) improving soil cover and hence reducing erosion, (3) extending afforestation on marginal agricultural land and managing existing woodland to ensure a mixed age structure of trees, and (4) growing renewable crops for bio-energy or product replacement (such as construction grade timber, e.g. Gustavsson et al. 2006). There is, however, debate about how the production of energy crops could affect air quality, soils, water use and biodiversity (e.g. Heaton et al. 1999, House of Lords EU Committee 2006, Wiesenthal et al. 2006, Eriksson \& Berg 2007). In particular, there is concern that reduced carbon emissions could be negated by rises in other greenhouse gases such as nitrous oxide and methane.

\section{CURRENT POLICY AND EMERGING ISSUES}

\subsection{Overview}

Changes in temperature and precipitation will have a range of physical impacts on upland areas, with some potential benefits to growing seasons and opportuni- ties for agriculture. However, these changes have a propensity to adversely affect the regulating ecosystem services uplands currently deliver; furthermore, changes in the frequency and intensity of extreme events could be outside the range of previous experience and overcome the resilience of ecosystems and damage their capacity to recover. Additional pressures could arise as a result of strategies to handle climate change, for example, increased demands for carbon and water storage. The uplands have always presented a particular set of policy challenges, for which some specific responses connected with economic development and conservation have been devised in the past. It is now time to look afresh at the policy agenda. This section considers the existing policy frameworks, how they can be used, and where they need strengthening to improve mitigation of climate change by the reduction of carbon emissions through land management and, secondly, to ameliorate the projected consequences of unavoidable climate change, such as floods and droughts. But there are limits. High rates of temperature change may exceed the adaptive capacity of natural or human systems in the uplands and could result in irreversible impacts: for example, loss of some protected montane habitats and potential loss of carbon storage facility in the soil. Facing the worst, were the ice sheets to melt, the uplands could constitute refuges for displaced people.

\subsection{Current upland policy strategy}

Opportunities for policy interventions are often limited because the UK uplands, and even National Parks, are not state or communally owned. Ultimately, land management is a function of actions taken by land managers, and these are often related to land tenure. Although some water companies and private interest groups concerned with conservation are land owners, purchase of land for environmental management is rare. Land ownership is clearly an important factor when evaluating policy options, given that $70 \%$ of the UK's 24 million ha belongs to just $1 \%$ of the population. The largest institutional landowners are the Forestry Commission (1 million ha), followed by the Ministry of Defence (300000 ha), the National Trust (222000 ha), the Crown Estate (162000 ha), and the Church of England (55000 ha). Private estates are also significant landholders, with the largest owning 110000 ha (Cahill 2001). A significant proportion of land is bought, not for its economic development potential, but for its status or investment value, reducing intervention opportunities still further. Land ownership in the uplands is hard to establish, although $50 \%$ of common land is in these areas, held mainly in 
private ownership and with multiple grazing rights. The National Trust owns 150000 ha in the uplands that is managed by tenants under essentially the same market pressures as other farmers in agriculturally marginal areas.

Public policy does have important entry points and levers through providing financial incentives, particularly the CAP, and also through regulation and control of water abstraction and discharge. Many significant policy frameworks that have an impact on upland land management are a function of separate policies in England, Scotland, Wales and Northern Ireland, although increasingly linked by the same external drivers (Table 2). These include the EU Water Framework Directive and the Floods Directive, the Habitats Directive, and international conventions, such as RAMSAR, or UNESCO's World Heritage Site designation (as proposed for the English Lake District). But these are not all yet 'climate proofed', that is, that the impacts of climate change or reduce greenhouse gas emissions have been reduced. At national levels, current public policy affecting uplands fall under sectoral policies for the water cycle (management of existing droughts and floods), spatial planning (regional spatial strategies and local development frameworks), biodiversity (SSSIs and other designated sites), landscape conservation (National Parks and protected areas), agriculture and forestry. Several of these policy levers are discussed below in terms of the level of 'climate proofing' they provide.

\subsection{Biodiversity policy}

After the Second World War, public policy focused on improving economic productivity of the uplands through intensification of forestry and agricultural activities and conifer plantations, acid grasslands and so-called 'improved' hill pastures replaced many of the more natural upland habitats (Mackey et al. 1998). Major policy reversal started in the early 1990s; for example, Habitat Action Plans have been published as part of the UK Biodiversity Action Plan to reverse these trends and to re-establish healthy and biodiverse up-

Table 2. Existing policy tools for climate change adaptation in the uplands. CFMP: Catchment Flood Management Plan; CAMS: Catchment Abstraction Management Strategies; WFD: Water Framework Directive; SSSI: Sites of Special Scientific Interest; SAC: Special Areas of Conservation; SPA: Special Protection Areas; RAMSAR: International Convention on Wetlands; RD: Rural Development; RDR: Rural Development Regulation

\begin{tabular}{|c|c|c|c|}
\hline Policy tool & Spatial scale & Horizon (review cycle) & $\begin{array}{l}\text { Relevance } \\
\text { to uplands }\end{array}$ \\
\hline CFMP & Catchment & Continuous ( 6 yr) & Yes \\
\hline CAMS & Catchment & Continuous (6 yr) & Yes \\
\hline Water Resource Strategy & Region & 25 yr $(5 \mathrm{yr})$ & Yes \\
\hline WFD & $\begin{array}{l}\text { River Basin Management Plan } \\
\text { (catchment and water body) }\end{array}$ & $18 \mathrm{yr}(6 \mathrm{yr})$ & Yes \\
\hline Making space for water & Catchment & Continuous & Yes \\
\hline Habitats and Birds Directive (SAC, SPA) & Full species range & $6 \mathrm{yr}$ & Yes \\
\hline Biodiversity action plans & Full species range & $3-5 \mathrm{yr}$ & Yes \\
\hline SSSI & Site based (10-15\% of Britain) & $\begin{array}{l}\text { No statutory requirement } \\
\text { but target dates (2010) }\end{array}$ & Yes \\
\hline RAMSAR wetland sites & Large sites & Continuous & Mainly Scotland \\
\hline $\begin{array}{l}\text { Areas of Outstanding Natural Beauty } \\
\text { (E\&W, National Scenic Areas) } \\
\text { (Scotland) - similar to National Parks }\end{array}$ & Large sites & Continuous (5 yr) & Limited number \\
\hline Forestry and woodland grants (RDR) & Field_catchment & Long-term & Yes \\
\hline National Nature Reserves & Site, often designated SSSI & Continuous (6 yr) & Limited area \\
\hline Agri-environment and associated schemes & Farm scale & $\sim 10 \mathrm{yr}$ & Yes \\
\hline Proposed uplands reward scheme (RDR) & Farm scale & $2007-2013$ & Yes \\
\hline National Parks & $\begin{array}{l}\text { Most of uplands of England } \\
\text { and Wales ( } 2 \text { in Scotland) }\end{array}$ & Continuous (5 yr) & Yes \\
\hline $\begin{array}{l}\text { Regional spatial strategy (not National } \\
\text { Parks) }\end{array}$ & Regions & $10-20 \mathrm{yr}$ & Yes \\
\hline National Nature Reserves & Site, often designated SSSI & Continuous (6 yr) & Limited \\
\hline $\begin{array}{l}\text { Strategic environmental assessment } \\
\text { (EU Directive) }\end{array}$ & $\begin{array}{l}\text { Limited to some larger } \\
\text { developments }\end{array}$ & Continuous & Limited \\
\hline
\end{tabular}


lands - the UK Government's target is $95 \%$ in favourable condition by 2010 (English Nature 2003). But there is a long way to go. A report on the status of SSSI sites in England found that $42 \%$ are in unfavourable condition, and most of these are in the uplands (English Nature 2003, Williams 2006). Primary reasons cited for poor condition were overgrazing (45\%), inappropriate burning $(24 \%)$ and drainage $(9 \%)$. It was also acknowledged that the effects of atmospheric pollution, particularly on bogs, are not fully understood. Nearly $20 \%$ of English SSSIs are on common land, where multiple ownership and grazing rights make land management agreements particularly difficult to coordinate - common land accounts for 35\% of 'moorland' and only $20 \%$ of such areas have joined agrienvironment schemes (Defra 2001).

Most uplands in England and Wales are covered by designations, but these have had mixed success as evidenced by the status of SSSIs. National Parks have acted to limit development in rural areas, but have had less impact on land conservation and resource management, despite having jurisdiction over much of the uplands and being well placed to implement more integrated adaptation strategies. Ensuring that all conservation-designated sites are in the best possible condition is most likely to improve ecosystem resilience and enhance adaptive capacity. Efforts to reduce overgrazing by co-ordinated agreements are being made, but are likely to take several years to have a discernable impact on biodiversity and may be threatened by greater economic returns from agriculture in the future. Other interventions such as protection and restoration of peatlands by drain blocking have been targeted at schemes and will require additional resources to become more widespread.

Guiding principles for conserving biodiversity in a changing climate have been identified (Hopkins et al. 2007), but resources to enact change are currently very limited, particularly for enhancing biodiversity as opposed to preventing deterioration (Piper et al. 2006). Concerns about migration potential and habitat fragmentation have led to calls for landscape approaches to habitat restoration, but the cost effectiveness and biodiversity gains of site-based conservation versus countrywide initiatives has yet to be established. This is partly due to a lack of systematic recording and availability of data from site-based conservation in the UK (Gaston et al. 2006) and evidence of 'what works' (Sutherland 2006). Upland habitats are in poor condition and are, by definition, isolated, but generally less fragmented than lowland habitats with the exception of native woodland (English Nature 2003). Undertaking defragmentation by connecting existing habitats along climatic and species migration axes could involve the creation of networks of protected areas and land in agri-environment schemes (e.g. Latham et al. 2004, Latham 2006), particularly where these exploit natural gradients (Hulme 2005) or landscape units (Table 3). Habitat creation is already a statutory requirement for major flood defence schemes in the UK and provides an additional opportunity.

The impact of climate change on freshwater ecosystems is highly uncertain and the subject of ongoing research (e.g. Conlan et al. 2007). The most effective adaptation option may be to enhance ecosystem resilience by reducing the impact of other co-stressors (Tables 3 and 4). However, we currently lack a full inventory of freshwater habitat extent and condition. Maps are available for terrestrial habitats at a range of spatial scales and levels of accuracy (e.g. landcover map [Fuller et al. 2002], habitat survey of Wales [Howe et al. 2005]). Although similar data are not available for freshwaters, site information is held for approximately 5000 sites from river habitat surveys (Raven et al. 1998), but these data need to be integrated with physical channel typologies to allow wider inferences to be made (Orr \& Walsh 2006).

Although a large number of species are likely to become extinct through loss of climate space, in many areas, a greater number continue to be threatened by land-use practices (Hannah et al. 2005). Conversely, other species may potentially gain from an expansion of their climate space, depending on suitable habitat being available (Walmsley et al. 2007). Thus, adaptation measures might include removal of physical barriers to migration, assisted natural recovery from overgrazing or channelisation, or reductions in diffuse pollution. However, the long-term conservation of key species such as salmon will depend on whether suitable climate space will be available; loss of lowland habitats may make upland sites even more valuable. Other measures can represent 'no regrets' options, for example, increasing the amount of riparian woodland, particularly in headwater streams could help buffer the effects of increasing water temperatures (Langan et al. 2001, Caissie 2006) and reduce sediment delivery (Lane et al. 2008). River restoration activities, particularly those that promote reconnection of channels with floodplains, can increase sediment deposition on floodplains, enhance storage of eroded soil and nutrients, reduce downstream flooding, improve in-channel habitats, and re-create sustainable floodplain wetlands (e.g. Shankman \& Pugh 1992, Erskine et al. 1999, Tockner et al. 1999). Creation of floodplain woodlands may also increase medium and long-term carbon sequestration (Robertson et al. 1999) and provide habitat to enable ecological migration as well as economic land uses where other types of crop production may be constrained (for example, by more frequent flooding). In some cases, conservation objectives might conflict 
Table 3. Landscape units linked to land management options

\begin{tabular}{|c|c|c|c|}
\hline Landscape unit & Land uses & Pressures & Potential options \\
\hline Uplands & All & All & Improve condition \\
\hline Fell tops & Grazing, recreation & $\begin{array}{l}\text { Overgrazing and trampling } \\
\text { leading to erosion }\end{array}$ & Reduce grazing, repair footpaths \\
\hline Upland gullies & Grazing, woodland & Erosion & Exclude stock, plant woodland \\
\hline Hillslopes & $\begin{array}{l}\text { Grazing, woodland, } \\
\text { forestry }\end{array}$ & Drainage, grazing & Block drainage, plant woodland \\
\hline $\begin{array}{l}\text { Upland confined } \\
\text { floodplains }\end{array}$ & Grazing & Drainage & Block drainage \\
\hline Blanket peat & $\begin{array}{l}\text { Grazing, forestry, } \\
\text { moorland sports }\end{array}$ & Grazing, footpath erosion, fire & $\begin{array}{l}\text { Reduce or remove grazing, block gullies and } \\
\text { drains, manage fire risk }\end{array}$ \\
\hline Gorges & Grazing, woodland & & Retain, manage and extend woodland \\
\hline Enclosed land & Grazing & $\begin{array}{l}\text { Sub-surface drainage, } \\
\text { diffuse pollution }\end{array}$ & $\begin{array}{l}\text { Field-scale soil and runoff management } \\
\text { (buffer strips, small wetlands, ditch manage- } \\
\text { ment, location of livestock facilities) }\end{array}$ \\
\hline Floodplains & $\begin{array}{l}\text { Grazing, silage, } \\
\text { limited crops }\end{array}$ & $\begin{array}{l}\text { Embankments, revetments, } \\
\text { drainage, intensive agriculture }\end{array}$ & $\begin{array}{l}\text { Channel restoration, floodplain reconnection, } \\
\text { floodplain woodland, wetland creation }\end{array}$ \\
\hline Riparian zones & Mixed & $\begin{array}{l}\text { Stock damage to banks, } \\
\text { diffuse pollution }\end{array}$ & $\begin{array}{l}\text { Create buffer zones, riparian woodland, } \\
\text { floodplain woodland, floodplain meadows }\end{array}$ \\
\hline River channels & & $\begin{array}{l}\text { Channelisation, abstraction, } \\
\text { pollution }\end{array}$ & Disconnect drains, maintain flow levels \\
\hline $\begin{array}{l}\text { Urban/settlement/ } \\
\text { tourist facilities }\end{array}$ & & $\begin{array}{l}\text { Sewerage, abstraction, runoff, } \\
\text { visitor pressure }\end{array}$ & $\begin{array}{l}\text { Management of private sewerage treatment, } \\
\text { composting toilets, ban on phosphate } \\
\text { detergents, encourage better water use }\end{array}$ \\
\hline Mines and quarries & & $\begin{array}{l}\text { Abandoned, unstable and } \\
\text { contaminated sediment and } \\
\text { runoff }\end{array}$ & $\begin{array}{l}\text { Stabilisation or removal of contaminated and } \\
\text { mobile sediment sources, management of } \\
\text { contaminated mine runoff }\end{array}$ \\
\hline
\end{tabular}

with climate change-related opportunities, for example, where intensive agricultural activities expand into the upland fringe due to a longer growing season or longer access period when soils are in workable condition (e.g. Carter \& Parry 1994). Resources for river restoration are currently limited and are largely available through capital works aimed at reducing flood risk; thus, being captured under water policy.

\subsection{Land-use policy}

The main land-use driver in the EU is the CAP, with its objectives to increase agricultural productivity, to ensure a fair standard of living for rural communities and to stabilise markets. Financial support for farmers is based on 2 'pillars', which influence production decisions. Pillar 1 covers market related subsidies; Pillar 2 covers rural development and sustainable use of resources in rural areas, providing assistance to difficult farming areas. Member states can select from a range of options in order to target specific needs (Dworak et al. 2005).

Current European policy on climate change takes into account the role of agriculture for climate change mitigation and recognises that the agricultural sector will have to adapt to secure food production and sustain the livelihoods of rural areas. Despite the lack of explicit references to adaptation in the current framework of the CAP, adaptation concerns might yet be integrated and supported through existing instruments. Before CAP reform, Pillar 1 was used to support change through product-related (coupled) payments without necessarily considering climatic or other environmental conditions. By introducing 'decoupling' as part of the 2003 CAP reform, market-based incentives became more relevant. Income support is still provided to the agricultural community, but its influence on production decisions is reduced, which leads to a larger role for the market in the determination of prices.

The new (2005) European Rural Development Regulation (RDR) also provides opportunities to strengthen the contribution of the CAP in combating climate change and supporting adaptation through Pillar 2. Climate change mitigation and adaptation are acknowledged as community priorities in the strategic guidelines for rural development, and member states are encouraged to incorporate appropriate actions in rural development (RD) programmes to address these priorities. Measures include: (1) direct support of new equipment needed for adaptation (e.g. Article 26 RDR modernisation of agricultural holdings); (2) support for the development of 
Table 4. Range of benefits of adaptive measures. DOC: dissolved organic carbon; HD: Habitats and Birds Directive; HLS: Higher Level agri-environment Scheme; other abbrevations, see Table 2

\begin{tabular}{|c|c|c|c|c|c|c|c|c|}
\hline \multirow{2}{*}{ Action } & \multicolumn{2}{|c|}{ Mitigation $\longrightarrow$} & \multicolumn{5}{|c|}{ Adaptation $\longrightarrow$} & \multirow{2}{*}{$\begin{array}{l}\text { Policy tools } \\
\text { WFD, HD }\end{array}$} \\
\hline & $\begin{array}{l}\text { Reduce soil } \\
\quad \text { C loss }\end{array}$ & $\begin{array}{l}\text { Improve } \\
\text { seques- } \\
\text { tration }\end{array}$ & $\begin{array}{l}\text { Improve water } \\
\text { holding capacity } \\
\text { of soil }\end{array}$ & $\begin{array}{l}\text { Reduce } \\
\text { erosion }\end{array}$ & $\begin{array}{l}\text { Reduce } \\
\text { runoff }\end{array}$ & $\begin{array}{c}\text { Improve } \\
\text { ecological } \\
\text { adaptive capacity }\end{array}$ & $\begin{array}{l}\text { Reduce } \\
\text { diffuse } \\
\text { pollution }\end{array}$ & \\
\hline $\begin{array}{l}\text { Grip } \\
\text { blocking }\end{array}$ & $\begin{array}{l}\text { Probably (DOC } \\
\text { reduction } 60-70 \% \text { ) }\end{array}$ & Yes & Yes & Yes & Yes & Yes & Yes & $\begin{array}{l}\text { SSSI, SAC, stewardship, } \\
\text { HLS }\end{array}$ \\
\hline Woodland & $\begin{array}{l}\text { Not initially but } \\
\text { gains in biomass, } \\
\text { soil stability }\end{array}$ & Yes & Yes & Yes & Yes & Yes & Yes & $\begin{array}{l}\text { Woodland grant scheme } \\
\text { and Forestry Commission }\end{array}$ \\
\hline $\begin{array}{l}\text { Destocking } \\
\text { uplands }\end{array}$ & Yes & Yes & Yes & Yes & Yes & Yes & Yes & $\begin{array}{l}\text { Land purchase, Common } \\
\text { Land agreements, HLS } \\
\text { stewardship }\end{array}$ \\
\hline $\begin{array}{l}\text { Changes in } \\
\text { burning practic }\end{array}$ & Unclear & Unclear & No & A bit & $\begin{array}{l}\text { On steep } \\
\text { slopes }\end{array}$ & Possibly & Maybe & $\begin{array}{l}\text { Stakeholder partnerships } \\
\text { and best practice } \\
\text { guidance, code of practice }\end{array}$ \\
\hline $\begin{array}{l}\text { Revegetation of } \\
\text { bare peat }\end{array}$ & Yes & Yes & Yes & Yes & Yes & Yes & Yes & $\begin{array}{l}\text { Remove stock, may need } \\
\text { land purchase, repair } \\
\text { footpaths }\end{array}$ \\
\hline $\begin{array}{l}\text { Wetland creation } \\
\text { (from grassland } \\
\text { arable) }\end{array}$ & d, & Yes & Yes & Yes & Yes & Yes & Yes & $\begin{array}{l}\text { Agri-env. schemes, HLS, } \\
\text { making space for water }\end{array}$ \\
\hline $\begin{array}{l}\text { Mine waste } \\
\text { removal or } \\
\text { stabilisation }\end{array}$ & - & - & Yes & - & - & Yes & Yes & $\begin{array}{l}\text { Ownership may be in } \\
\text { question, forthcoming } \\
\text { EU Minewaters Directive } \\
(2007 / 2008)\end{array}$ \\
\hline
\end{tabular}

new products, processes and technologies in the agricultural, food and forestry sector (Article 29 RDR); and (3) educational measures (e.g. Article 22 RDR and Article 58 RDR). In addition, the 2007 to 2013 RDR provides an opportunity to set up measures that aim to restore agricultural production damaged by 'natural' disasters (e.g. flooding) and introducing appropriate prevention actions (Article 20 [b] [Vi] RDR). The commission has also developed possibilities to introduce new risk and crisis management measures into the menu of rural development policy. It suggests instruments such as financial contributions to premiums paid by farmers for insurance against natural disaster, support for mutual funds in the agricultural sector, and a generalised approach to respond to income crises. Awareness of risk exposure to climate change through the increasing frequencies of extreme events might provide an additional stimulus to further pursue such approaches.

Depending on the priorities set by the member states, measures provided by the new RDR can therefore be used to encourage the adaptation process. It is important to note that the total share of CAP funding spent on Pillar 2 is still small compared to the sums available under Pillar 1. This should be considered when assessing the potential options to adapt to climate change in the agricultural sector.
The UK has provided support to upland areas since 1975 through the EU Less Favoured Areas Support Scheme to support farming where production conditions are difficult. Most of this land is used for either rough or improved grazing. New schemes are now being introduced with a broader suite of environmental considerations that could include adaptation and mitigation responses by supporting high water quality, reducing flood risk, ameliorating droughts, encouraging carbon sequestration and supporting wildlife. They may need to be sufficiently flexible to enable targeting and to take local conditions into account (e.g. Tables 3 \& 4). A range of options are available (Fig. 4) with obvious cost implications, some of which may become more 'justified' or cost effective under future climate change.

Ultimately, socio-economic factors will dictate the recognition of priority measures at the regional/local level. It is therefore imperative that climate change responses are directly included within these deliberations and therefore targeted within that regional/local land-use context, rather than implemented as generic or separate schemes. Evidence from implementation of agri-environmental schemes has shown that neglecting this cultural context tends to result in limited success (e.g. Burton et al. 2008). 


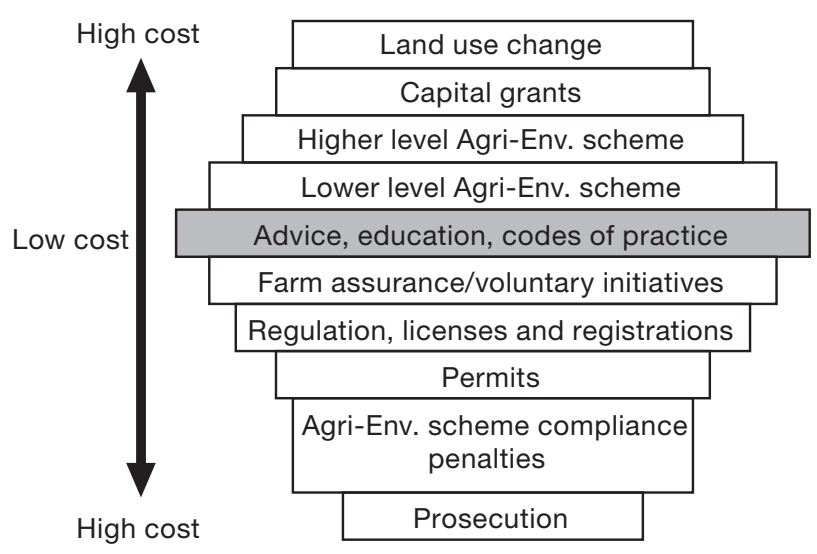

Fig. 4. Toolkit for change in the agricultural sector (source: H. Wakeham, Environment Agency, pers. comm.)

Increasingly, land use is likely to be affected by policies aimed at mitigating climate change. Carbon, methane and nitrous oxide emissions from land use are receiving greater attention both globally and in the UK (HM Government 2006, Stern 2006). Work is underway in the UK and EU to see whether market mechanisms such as a trading scheme can be used within the agricultural sector. Best practice guidance could be established, for example, through Carbon Aware Land Management (CALM) and the use of simple farm-scale carbon accounting tools (e.g. Viner et al. 2006). However, verification of soil carbon sequestration within the context of the national targets set within the United Nations Framework Convention on Climate Change (UNFCCC) is not straightforward (Dawson \& Smith 2008), and controlling methane or nitrous oxide emissions is extremely difficult with so many sources involved (Smith et al. 2007a). Nonetheless, the opportunities for generating revenue from carbon management should not be ignored. Globally, there is increased pressure for land-use stocks to be brought within a post-2012 climate deal. The estimated environmental cost of soil organic carbon loss in 1996 was £106 million (Pretty et al. 2000). Overall, there is limited scope to enhance the sequestration potential of uplands. Two possibilities include the growing of biofuel and biomass crops on the upland fringe, assuming sufficient water availability, and woodland or forestry planting and management. Wood production may provide the best carbon savings when used as a substitute for more $\mathrm{CO}_{2}$ intensive material manufacture. Perhaps more critical is to ensure steps are taken to protect existing carbon stores by stopping bad practice such as over-grazing, drainage, or burning. Furthermore, within the clear imperative of emission-reduction targets, there is also an over-riding need that mitigation schemes do not significantly hinder effective adaptation strategies, for example, that areas of new woodland are also integrated with biodiversity and water resource objectives.

\subsection{Water policy}

In England and Wales water abstraction is granted under licence and is regulated through Catchment Abstraction Management Strategies (CAMS). These are reviewed every 5 yr within a larger Water Resource Strategy, which looks $25 \mathrm{yr}$ ahead and is a mechanism for climate change adaptation. At the current time the majority of licence abstractions are granted indefinitely, although the Environment Agency has powers to revoke these. This may become particularly significant in upland areas that are key water resource zones and often have small water supplies that may be unsustainable under both future climate change and the new requirement to achieve good ecological status (GES) in all water bodies under the EU WFD.

The main policy tool for flood risk management in England and Wales is now the Catchment Flood Management Plan (CFMP). This flexible framework will identify broad policies for sustainable flood risk management that make sense in the context of a whole catchment and for the long term (50 to $100 \mathrm{yr}$ ). Climate and land-use changes can be built into considerations of how flood risk may change within the catchment. Both CAMS and CFMP will be used in River Basin District Plans (RBMPs) to implement the WFD and collectively present a significant opportunity to consider climate change adaptation measures at a range of spatial scales.

Abstraction licensing and strategic flood risk management have not formed part of the policy framework in Scotland prior to implementation of the WFD. New regulation has been established specifically aimed at delivery of the WFD (Water Environment [Controlled Activities] Regulations 2005 [CAR] and the forthcoming Floods Bill). Historically, voluntary Flood Appraisal Groups (now called Flood Liaison and Advice Groups) influenced flood policies and decision making via local government authorities, but their powers were nonstatutory and they did not usually extend to non-agricultural land or whole catchments (Scottish Executive 2004).

In the UK, cross sectoral 'Making Space for Water' policies advocate catchment-wide management as an alternative to hard engineering solutions for local flood risk management (Defra 2005a). More research is needed on the costs and benefits of land management as a tool for reducing flooding. Consideration needs to be given to the landscape and catchmentscale effectiveness of local interventions (e.g. Lane et al. 2003, Defra 2005b). Cost-benefit analysis should consider the full range of environmental gains from actions aimed primarily at ameliorating flood impacts (Table 4). 


\subsection{Integrating policy challenges}

Protecting the ecosystem services provided by the uplands will require adaptation planning at national and strategic levels, whilst implementation of adaptive measures needs to be undertaken at more local scales, but in an integrated way. This requires: (1) improved scientific information, for example, validated impact/adaptation models and downscaled climate change scenarios; (2) scoping of adaptation options and integrated assessment of outcomes; and (3) guidance for environmental managers and delivery mechanisms for achieving positive adaptation.

No single agency has responsibility for climate change adaptation, and integrated delivery may best be achieved through existing stakeholder partnerships (including rural development agencies) and new ways of working (e.g. Edwards Jones et al. 2007). The greatest opportunities through existing mechanisms, in terms of scope and area are perhaps through WFD and National Parks (see Table 2), because these have an integrated agenda and strong links with spatial planning frameworks. The WFD options appraisal stage will enable assessment of the socio-economic implications of adopting particular measures and the risks of 'doing nothing'.

The WFD RBMPs may provide a structure for interdisciplinary and inter-agency working (Wilby et al. 2006), but need to be supported by information on climate change impacts at regional and catchment scales. Organisations such as river trusts are now widespread in the UK (see www.associationofriverstrusts.org.uk), and are well placed to effect changes at catchment scales, because many already have active stakeholder partnerships based upon a shared 'vision' of the future and direct influence over land management. Community involvement in such initiatives is also critical and can lead to greater awareness and acceptance of change (e.g. www.lake-district.gov.uk/bassenthwaite/ for the Bassenthwaite Restoration Programme).

Key challenges include reducing the number of grazing animals, addressing concerns and perceptions about the invasion of scrub vegetation and limited resources for biodiversity, habitat conservation and river restoration. Some issues could be addressed by research that identifies the benefits of upland management to other sectors such as water colour treatment likely to become increasingly expensive and difficult under climate change (Worrall \& Burt 2005). Voluntary and subsidised agri-environment schemes may be limited in terms of scale of effectiveness unless there is scope for land purchase or other economic returns from managing land just for the water resource for example. There are currently few policy tools that link terrestrial and freshwater processes (Tables $2 \& 3$ ); the
WFD is largely aspirational with respect to land use, but is likely to be strengthened by the EU Thematic Strategy for Soil Protection (adopted in 2006), which includes a Soils Directive.

The water industry in England and Wales is tightly regulated and, whilst traditionally focussed on 'end of pipe solutions', there is increasingly a move towards 'catchment solutions' to long-term water-quality problems. However, the mechanisms for paying for catchment solutions would require significant change for these to become widespread.

Ultimately, water management is heavily regulated, but land management is not. Climate-driven risks to the largely free or cheap services uplands deliver may require new economic instruments to provide these services in the future.

\section{RESEARCH PRIORITIES}

Development of robust, evidence-based, best practice and guidance on climate change adaptation in the uplands will be aided by addressing knowledge gaps in: (1) soil carbon biophysical properties, carbon fluxes, climate and land-use drivers; (2) the effectiveness of land management in reducing hazards such as flooding, drought and erosion; and (3) the impacts of climate change on freshwater ecosystems. These themes should further address how and where adaptive measures will have the greatest impact on reducing vulnerability to climate change (e.g. Lane et al. 2003) and how we can ensure that climate change impacts are 'detectable' and that gains from land management intervention can be demonstrated. In addition to monitoring and modelling of current processes, future projections of change, e.g. using scenario analysis (climate and land use), are important for developing anticipatory adaptation responses. Demonstration projects may help to investigate resilience, communicate best practice and manage for uncertainty.

The carbon gains, losses and sequestration potential of land-use types are broadly understood (Table 5), although better quantification is needed (Bellamy et al. 2005, Kuzyakov 2006, Lund 2006). There could be substantial economic gains for land managers if carbon sequestration can be verified. Tools are needed to scale up field- and farm-scale sequestration to landscape and catchment scales. The carbon uptake also needs to be durable. Changes in management may only retard carbon loss from peatlands in the short term (Cleary et al. 2005), particularly if long-term changes in climate lead to peatland degradation. However, improving the condition and preventing further degradation of existing peatlands may secure the present carbon stock and favour other ecosystem services. 
Table 5. Carbon sequestration and storage potential from different land use, land-use conversion and management changes (all data from a variety of sources reported in Dawson \& Smith [2008], large uncertainties are attached to these). -: soil C loss; +: soil C gain

\begin{tabular}{|lc|}
\hline Land use & Carbon $\left(10^{3} \mathrm{kgC} \mathrm{ha}^{-1} \mathrm{yr}^{-1}\right)$ \\
\hline Storage potential & \\
Native vegetation grassland & 0.35 \\
Peatland cultivation & -2.2 to -5.4 \\
Moorland to grassland & -0.9 to -1.1 \\
Grassland to afforestation & 0.1 \\
Wetland restoration & $0.1-1.0$ \\
Revegetation on wetlands from grassland & $0.8-3.9$ \\
Grassland to arable & -1.0 to -1.7 \\
Forestry to grassland & -0.1 \\
& \\
Sequestration potential & $0.2-0.5$ \\
UK peatland, natural accumulation & $($ long-term may be 0.7$)$ \\
(undrained) & $0.091-0.180$ \\
Short rotation coppice & $0.033-0.119$ \\
Marginal crop to forest & $0.138-0.190$ \\
Increasing growth of construction timber & -0.9 to 1.1 \\
Intensification of nutrient-poor grassland & \\
\hline
\end{tabular}

Verification and economic analysis of multiple benefits could strengthen incentives to protect uplands.

In addition to research on soil biophysical processes, continuous measurements of DOC and POC are needed to monitor soil erosion and the outcomes of land management decisions. Integrating phosphorus and carbon monitoring would also be beneficial for assessing compliance with WFD, the Habitats Directive and the forthcoming Soils Directive. There may be opportunities here to link with monitoring under Defra's catchment sensitive farming (CSF) initiative. This could provide more data on the impact of land use as there are currently large uncertainties associated with the methodology for measuring carbon loss by in situ soil sampling. In addition, more research is required on the loss of carbon from mineral soils (Quinton et al. 2006), as these may be under-represented in Defra's database (Bellamy et al. 2005).

UK uplands have a high proportion of sites designated for conservation and special protection; more focussed monitoring could help assess biodiversity and ecological response to climate under constant management regimes in a cost-effective way (Sutherland 2006). The data could help produce climate-sensitive landscape ecology models to indicate where habitat networks could be improved. Data on freshwater ecology, temperature, water quality, hydrology and physical habitat could be integrated for climate-sensitivity testing. But there is also a need to scale up understanding of climate change impacts on freshwaters in order to make national and regional strategic assessments and ensure resources are effectively targeted.

\section{CONCLUDING REMARKS}

The present condition of many UK uplands and the increasing pressures expected under climate change are cause for concern. The present review highlights the need for better management, particularly with regard to the linkages between terrestrial and freshwater environments. Constraints and opportunities for doing so within existing policy frameworks and research priorities have been discussed. Some of the wider limitations to effective climate change mitigation and adaptation in the uplands include a lack of spatial planning in the rural environment, regulatory control of land use and management, recognition for services delivered by uplands to downstream areas and viable economic incentives to protect these areas that are also consistent with their cultural contexts. A general policy framework to integrate and tackle these issues in the UK has recently been proposed through an Ecosystems Services Action Plan (Defra 2007b). Coupled with development of climate change policy on both mitigation and adaptation, incentivised through the Climate Change Bill, there is scope for a major re-framing of upland strategies. This opportunity should be taken.

Acknowledgements. This review was supported by Environment Agency Project SC050055. The views expressed in this paper are those of the authors and not necessarily indicative of the position held by the Environment Agency. Three anonymous reviewers are thanked for their suggested improvements.

\section{LITERATURE CITED}

Aerts CJH, Droogers P (eds) (2004) Climate change in contrasting river basins: adaptation strategies for water food and environment. CABI, Oxfordshire

Andersen RS, Towers W, Smith P (2005) Assessing the potential for biomass energy to contribute to Scotland's renewable energy needs. Biomass Bioenergy 29:73-82

Araújo MB, Pearson RG, Thuiller W, Erhard M (2005) Validation of species-climate impact models under climate change. Glob Change Biol 11:1504-1513

Arnell NW (2003) Relative effects of multi-decadal climatic variability and changes in the mean and variability of climate due to global warming: future streamflows in Britain. J Hydrol 270:195-213

Audsley E, Pearn KR, Simota C, Cojocaru G and others (2006) What can scenario modelling tell us about future European scale land use, and what not? Environ Sci Policy 9: 148-162

Averis A, Averis B, Birks J, Horsfield D, Thompson D, Yeo M (2004) An illustrated guide to British upland vegetation. Joint Nature Conservation Committee, Peterborough 
Barker PA, Wilby RL, Borrows J (2004) A 200 year precipitation index for the Central English Lake District. Hydrol Sci J 49:769-785

Barnett C, Hossell J, Perry M, Procter C, Hughes G (2006) A handbook of climate trends across Scotland. SNIFFER Project CC03, Scotland and Northern Ireland Forum for Environmental Research. Available at www.sniffer.org. uk/climatehandbook/

Barry RG (2003) Mountain cryospheric studies and the WCRP climate and cryosphere (CliC) project. J Hydrol 282: 177-181

Battarbee RW, Curtis CJ, Binney HA (eds) (2005) The future of Britain's upland waters. In: Proceedings of a meeting held on 21 April 2004. Environmental Change Research Centre, University College London. Ensis Publishing, London

Beale CM, Burfield IJ, Sim IMW, Rebecca GW, PearceHiggins JW, Murray CG (2006) Climate change may account for the decline in British ring ouzels Turdus torquatus. J Anim Ecol 75:826-835

Bellamy PH, Loveland PJ, Bradley RA, Lark RM, Kirk GJD (2005) Carbon losses from all soils across England and Wales. Nature 437:245-248

Beniston M (2003) Climatic change in mountain regions: a review of possible impacts. Clim Change 59:5-31

Beniston M (2006) Mountain weather and climate: a general overview and a focus on climatic change in the Alps. Hydrobiologia 562:3-16

Beniston M, Diaz HF, Bradley RS (1997) Climatic change at high elevation sites: an overview. Clim Change 36: 233-251

Berry PM, Dawson TP, Harrison PA, Pearson RG, Butt N (2003) The sensitivity and vulnerability of terrestrial habitats and species in Britain and Ireland to climate change. J Nat Conserv 11:15-23

Bjornsen Gurung A (ed) (2005) GLOCHAMORE-Global change and mountain regions: research strategy. Mountain research initiative, Zurich

> Black AR, Burns JC (2002) Re-assessing the flood risk in Scotland. Sci Total Environ 294:169-184

> Bradley RI, Milne R, Bell J, Lilly A, Jordan C, Higgins A (2005) A soil carbon and land use database for the United Kingdom. Soil Use Manage 21:363-369

Bradley RS, Vuille M, Diaz HF, Vergara W (2006) Threats to water supplies in the tropical Andes. Science 312: 1755-1756

Bragg OM (2002) Hydrology of peat-forming wetlands in Scotland. Sci Total Environ 294:111-129

Bragg OM, Tallis JH (2001) The sensitivity of peat covered upland landscapes. CATENA 42:345-360

Burt TP (2001) Integrated management of sensitive catchment systems. CATENA 42:275-290

> Burt S (2005) Cloudburst upon Hendraburnik Down: the Boscastle storm of 16 August 2004. Weather 60:219-227

> Burton RJF, Kuczera C, Schwarz G (2008) Exploring farmers' cultural resistance to voluntary agri-environmental schemes. Sociol Ruralis 48:16-37

Cahill K (2001) Who owns Britain? The hidden facts behind land ownership in Britain and Ireland. Canongate, Edinburgh

Caissie D (2006) The thermal regime of rivers: a review. Freshw Biol 51:1389-1406

Carroll ZL, Bird SB, Emmett BA, Reynolds B, Sinclair FL (2004) Can shelterbelts on agricultural land reduce flood risk? Soil Use Manage 20:357-359

Carter TR, Parry MF (1994) Evaluating the effects of climate change on marginal agriculture in upland areas. In: Beniston $\mathrm{M}$ (ed) Mountain environments in changing climates. Routledge, London, p 405-421

> Chiverrell RC, Harvey AM, Foster GC (2007) Hillslope gullying in the Solway Firth-Morecambe Bay region: Re- sponses to human impact and/or climatic deterioration? Geomorphology 84:317-343

Christensen JH, Hewitson B, Busuioc A (2007) Regional climate projections. In: Solomon S, Quin D, Manning M, Chen Z and others (eds) Climate Change 2007: the physical science basis. Contribution of Working Group I to the 4th Assessment Report of the Intergovernmental Panel on Climate Change, Cambridge University Press, Cambridge

Cleary J, Roulet NT, Moore TR (2005) Greenhouse gas emissions from Canadian peat extraction, 1990-2000: a life cycle analysis. Ambio 34:456-461

Collinson N, Sparks T (2003) The science that redefines the seasons. Recent studies from the UK Phenology network. British Wildlife 14:229-232

Conlan K, Lane S, Ormerod S, Wade T (2005) Preparing for climate change impacts on freshwater ecosystems (PRINCE): literature review and proposed methodology. No. SCHO0805BJJF-EP, Science Report to Environment Agency, Bristol

Conlan K, Lane S, Ormerod S, Wade T (2007) Preparing for climate change impacts on freshwater ecosystems (PRINCE): results. No. SC030300/SR, Science Report to Environment Agency, Bristol

Cox PM, Betts RA, Jones CD, Spall SA, Totterdell IJ (2000) Acceleration of global climate change due to carbon-cycle feedbacks in a coupled climate model. Nature 408:184-187

Crooks S (2006) Progress report on snowpack modelling. Regionalised impacts of climate change on flood flows. FD2020 Project, CEH, Wallingford

Curry Report (2002) Farming and food a sustainable future. Policy commission on the future of farming and food, chaired by Sir Don Curry, January 2002. Cabinet Office, London

Curtis CJ, Evans CD, Helliwell RC, Monteith DT (2005) Nitrate leaching as a confounding factor in chemical recovery from acidification in UK upland waters. Environ Pollut 137:73-82

Dadson SJ, Church MA (2005) Post-glacial topographic evolution of glaciated valleys: a stochastic landscape evolution model. Earth Surf Process Landf 30:1387-1403

Davidson IC, Hazelwood MS (2005) Effect of climate change on salmon fisheries. Science Report W2-047/SR, Environment Agency, Bristol

Davidson EA, Janssens IA (2006) Temperature sensitivity of soil carbon decomposition and feedbacks to climate change. Nature 440:165-173

Dawson JJC, Smith P (2008) Carbon losses from soil and its consequences for land management. Sci Total Environ (in press), doi: 10.1016/j.scitotenv.2007.03.023

Defra (Department for Environment, Food and Rural Affairs) (2000) Agriculture and water quality: a diffuse pollution review. Defra, London

Defra (2001) Report of the task force for the hills. Available at: www.hillfarming.org.uk/index.html

Defra (2004) Review of UK climate change indicators. Contract EPG 1/1/158, Defra, London

Defra (2005a) Making space for water: taking forward a new government strategy for flood \& coastal erosion risk management. Defra, London

Defra (2005b) Review of impacts of rural land use and management on flood generation: impact study report. Report FD2114/TR, Defra, London

Defra (2006) Rural development programme for England 2007-2013: upland rewards structure. Consultation document February 2006, Defra, London

Defra (2007a) The June agricultural survey. Available at: www. defra.gov.uk/esg/work_htm/publications/cs/farmstats_web/

Defra (2007b) Securing a healthy environment: an action plan 
for embedding an ecosystemns approach. Defra, London Dixon H, Lawler DM, Shamseldon AY (2006) Streamflow trends in western Britain. Geophys Res Lett 33: L19406L19407

> Dockerty T, Lovett A, Watkinson A (2003) Climate change and nature reserves: examining the potential impacts, with examples from Great Britain. Glob Environ Change 13:125-135

> Driscoll CT, Driscoll KM, Roy KM, Mitchell MJ (2003) Chemical response of lakes in the Adirondack Region of New York to declines in acidic deposition. Environ Sci Technol 37:2036-2042

> Durance I, Ormerod SJ (2007) Impacts of climatic variation on upland stream invertebrates over a 25 year period. Glob Change Biol 13:942-957

Dworak T, Karaczun ZM, Herbke N, Schlegel S, LandgrebeTrinkunaite R (2005) WFD and Agriculture linkages at the EU level, final report about Rural Development Programmes. Final version. Warsaw Agricultural University and Eco-logic, Warsaw

Edwards-Jones G, Harris IM, Dyer J, Wragg A (2007) Climate proofing rural resource protection policies and strategies in Wales. Report No. SCHO 0407BMGX:230, Environment Agency, Bristol

EEA (European Environment Agency) (2007) Climate change and water adaptation issues. Technical Report No. 2/2007, EEA, Copenhagen

Ellis TW, Leguédois S, Hairsine PB, Tongway DJ (2006) Capture of overland flow by a tree belt on a pastured hillslope in south-eastern Australia. Aust J Soil Res 44:117-125

English Nature (2003) England's best wildlife and geological sites - the condition of sites of special scientific interest in England in 2003. English Nature, Peterborough

Eriksson E, Berg S (2007) Implications of environmental quality objectives on the potential of forestry to reduce net $\mathrm{CO}_{2}$ emissions - a case study in central Sweden. Forestry 80: 99-111

Erskine WD, Terrazzollo N, Warner RF (1999) River rehabilitation from the hydrogeomorphic impacts of a large hydro-electric power project: Snowy River, Australia. Regul Rivers Res Manage 15:3-24

European Commission (2005) Communication from the commission to the council on risk and crisis management in agriculture. Commission of the European Communities COM (2005) 74, Brussels

Evans CD, Monteith DT (2001) Chemical trends at lakes and streams in the UK Acid Waters Monitoring Network, 1988-2000. Evidence for recent recovery at a national scale. Hydrol Earth Syst Sci 5:351-366

Evans CD, Jenkins A, Helliwell R, Ferrier R, Collins R (2001) Freshwater acidification and recovery in the United Kingdom. Centre for Ecology and Hydrology Report, Wallingford

Evans E, Ashley R, Hall J, Penning-Rowsell E and others (2004) Foresight. Future flooding. Scientific summary, Vol I. Future risks and their drivers. Office of Science and Technology, London

Evans CD, Chapman PJ, Clark JM, Monteith DT, Cresser MS (2006) Alternative explanations for rising dissolved organic carbon from organic soils. Glob Change Biol 12:2044-2053

Evans M, Warburton J, Yang J (2006b) Eroding blanket peat catchments: global and local implications of upland organic sediment budgets. Geomorphology 79:45-57

Fowler HJ, Kilsby CG (2003) A regional frequency analysis of United Kingdom extreme rainfall from 1961 to 2000. Int J Climatol 23:1313-1334

Fowler HJ, Kilsby CG (2007) Using regional climate model data to simulate historical and future river flows in north west England. Clim Change 80:337-367
Freeman C, Evans CD, Monteith DT, Reynolds B, Fenner N (2001a) Export of organic carbon from peat soils. Nature 412:785

> Freeman C, Ostle N, Kang H (2001b) An enzyme latch on a global carbon store-a shortage of oxygen locks up carbon in peatlands by restraining a single enzyme. Nature 409: 149

- Freeman C, Fenner N, Ostle NJ, Kang H and others (2004) Export of dissolved organic carbon from peatlands under elevated carbon dioxide levels. Nature 430:195-198

Fuller RM, Smith GM, Sanderson JM, Hill RA, Thomson AG (2002) The UK Land Cover Map 2000: construction of a parcel-based vector map from satellite images. Cartographic J 39: 15-25

Gaston KJ, Charman K, Jackson SF, Armsworth PR and others (2006) The ecological effectiveness of protected areas: the United Kingdom. Biol Conserv 132:76-87

George DG, Maberly SC, Hewitt DP (2004) The influence of the North Atlantic Oscillation on the physical, chemical and biological characteristics of four lakes in the English Lake District. Freshw Biol 49:760-774

Gilles D, Christian W, Nicole M, Lucien H, Laurent P (2006) Topography and recent winter rainfall regime change in temperate western European areas: a case study in the Rhine-Meuse basin. Int J Climatol 26:785-796

Golding B, Clark P, May B (2005) The Boscastle flood: meteorological analysis of the conditions leading to flooding on 16 August 2004. Weather 60:230-235

Groisman PY, Knight RW, Easterling DR, Karl TR, Hegerl GC, Razuvaev VN (2005) Trends in intense precipitation in the climate record. J Clim 18:1326-1350

Gustavsson L, Pingoud K, Sathre R (2006) Carbon dioxide balance of wood substitution: comparing concrete- and wood-framed buildings. Mitig Adapt Strategies Glob Change 11:667-691

> Hannaford J, Marsh T (2006) An assessment of trends in UK runoff and low flows using a network of undisturbed catchments. Int J Climatol 26:1237-1253

- Hannah L, Midgley G, Hughes G, Bomhard B (2005) The view from the cape: extinction risk, protected areas, and climate change. Bioscience 55:231-242

Harrison J, Winterbottom S, Johnson R (2001) Climate change and changing snowfall patterns in Scotland. Scottish Executive Central Research Unit, Edinburgh

> Hatfield RG, Maher BA (2008) Suspended sediment characterisation and tracing using a magnetic fingerprinting technique: Bassenthwaite Lake, Cumbria, UK. Holocene 18:105-115

> Heaton RJ, Randerson PF, Slater FM (1999) The economics of short rotation coppice in the uplands of mid-Wales and an economic comparison with sheep production. Biomass Bioenergy 17:59-71

Hejzlar J, Dubrovsky M, Buchtele J, Ruzicka M (2003) The apparent and potential effects of climate change on the inferred concentration of dissolved organic matter in a temperate stream (the Malse River, South Bohemia). Sci Total Environ 310:143-152

> Helliwell RC, Davies JJL, Evans CD, Jenkins AJ and others (2007) Spatial and seasonal variations in nitrogen leaching and acidity across four acid-impacted regions of the UK. Water Air Soil Pollut 185:3-19

> Hickling R, Roy DB, Hill JK, Fox R, Thomas CD (2006) The distribution of a wide range of taxonomic groups are expanding polewards. Glob Change Biol 12:450-455

Hill MO, Downing TE, Berry PM, Coppins BJ and others (1999) Climate changes and Scotland's natural heritage: an environmental audit. Scottish Natural Heritage Research, Survey and Monitoring Report No. 132, Scottish 
Natural Heritage, Battleby

HM Government (2006) Climate change. The UK Programme CM6764, The Stationery Office (TSO), London

Hobbs RJ, Arico S, Aronson J, Baron JS and others (2006) Novel ecosystems: theoretical and management aspects of the new ecological world order. Glob Ecol Biogeogr 15: $1-7$

Holden J, Adamson JK (2002) The Moor House long-term upland temperature record: new evidence of recent warming. Weather 57:119-127

Holden J, Shotbolt L, Bonn A, Burt TP and others (2007) Environmental change in moorland landscapes. Earth Sci Rev 82:75-100

Holman IP, Rounsevell MDA, Shackley S, Harrison PA, Nicholls RJ, Berry PM, Audsley E (2005) A regional, multisectoral and integrated assessment of the impacts of climate and socio-economic change in the UK. I. Methodology. Clim Change 71:9-41

Hopkins JJ, Allison HM, Walmsley CA, Gaywood M, Thurgate G (2007) Conserving biodiversity in a changing climate: guidance on building capacity to adapt. Department for Environment, Food and Rural Affairs, London

Hossell JE, Briggs B, Hepburn IR (2000) Climate change and UK nature conservation: a review of the impact of climate change on UK species and habitat conservation policy. DETR, HMSO, London

Hossell JE, Riding AE, Brown I (2003) The creation and characterisation of a bioclimatic classification for Britain and Ireland. J Nat Conserv 11:5-13

House of Lords EU Committee (2006) The EU strategy on biofuels: from field to fuel. HL Paper 267-I:59, Stationary Office, London

Howe L, Blackstock T, Burrows C, Stevens J (2005) The habitat survey of Wales. British Wildlife 16:153-162

Hulme PE (2005) Adapting to climate change: Is there scope for ecological management in the face of a global threat? J Appl Ecol 42:784-794

Hulme M, Jenkins GJ, Lu X, Turnpenny JR and others (2002) Climate change scenarios for the UK. The UKCIP02 Scientific Report, Tyndall Centre for Climate Change Research, School of Environmental Sciences, University of East Anglia, Norwich

Huntley B, Webb T III (1989) Migration: species' response to climatic variations caused by changes in the Earth's orbit. J Biogeogr 16:5-19

IPCC (Intergovernmental Panel on Climate Change) (2000) Special report on emissions scenarios. Report of Working Group III of the IPCC, Cambridge University Press, Cambridge

IPCC (2007) Summary for policymakers. In: Parry ML, Canziani OF, Palutikof JP, van der Linden PJ, Hanson CE (eds) Climate change 2007: impacts, adaptation and vulnerability. Contribution of Working Group II to the 4th assessment report of the IPCC. Cambridge University Press, Cambridge, p 7-22

Jackson JK, Füreder L (2006) Long-term studies of freshwater macroinvertebrates: a review of the frequency, duration and ecological significance. Freshw Biol 51:591-603

Janssens IA, Freibauer A, Ciais P, Smith P and others (2003) Europe's terrestrial biosphere absorbs 7 to $12 \%$ of European anthropogenic $\mathrm{CO}_{2}$ emissions. Science 300: 1538-1542

Janzen HH (2006) The soil carbon dilemma: Shall we hoard it or use it? Soil Biol Biochem 38:419-424

> Jasper K, Calanca P, Gyalistras D, Fuhrer J (2004) Differential impacts of climate change on the hydrology of two alpine river basins. Clim Res 26:113-129

> Johnson P (2005) Snow cover on the Cumbrian mountains. Weather 60:132-135
Johnson RM, Warburton J (2002) Flooding and geomorphic impacts in a mountain torrent: Raise Beck, Central Lake District, England. Earth Surf Process Landf 27:945-969

Jones DKC (1993a) Global warming and geomorphology. Geogr J 159:124-130

> Jones DKC (1993b) Slope stability in a warmer Britain. Geogr J 159:184-195

Jones B, Gliddon C (1999) Reproductive biology and genetic structure in Lloydia serotina. Plant Ecol 141:151-161

Jones DKC, Lee EM (1994) Landsliding in Great Britain. Dept of Environment, HMSO, London

Kapos V, Rhind J, Edwards M, Price MF, Ravilious C (2000) Developing a map of the world's mountain forests. In: Price MF, Butt N (eds) Forests in sustainable mountain development: a state-of-knowledge report for 2000. IUFRO Series No. 5, CAB International, Wallingford, p 4-9

Karoly DJ, Stott PA (2006) Anthropogenic warming of central England temperature. Atmos Sci Lett 7:81-85

- Klanderud K, Birks HH (2003) Recent increases in species richness and shifts in altitudinal distributions of Norwegian mountain plants. Holocene 13:1-6

Kuzyakov Y (2006) Sources of $\mathrm{CO}_{2}$ efflux from soil and review of partitioning methods. Soil Biol Biochem 38:425-448

> Laiho R (2006) Decomposition in peatlands: reconciling seemingly contrasting results on the impacts of lowered water levels. Soil Biol Biochem 38:2011-2024

Lane SN, Brookes CJ, Hardy RJ, Holden J and others (2003) Land management, flooding and environmental risk: new approaches to a very old question. In: Proc. CIWEM National Conference. Chartered Institute of Water and Environment Management, Harrogate

> Lane SN, Reid SC, Tayefi V, Yu D, Hardy RJ (2007) Interactions between sediment delivery, channel change, climate change and flood risk in a temperate upland environment. Earth Surf Process Landf 32:429-446

> Lane SN, Reid SC, Tayefi V, Yu D, Hardy RJ (2008) Reconceptualising coarse sediment delivery problems in rivers as catchment-scale and diffuse. Geomorphology 98:227-249

> Langan SJ, Johnston L, Donaghy MJ, Youngson AF, Hay DW, Soulsby C (2001) Variation in river water temperatures in an upland stream over a 30 -year period. Sci Total Environ 265:195-207

Latham J (2006) Forest habitat networks for Wales. Q J Forestry 100:280-284

Latham J, Watts K, Thomas C, Griffiths M (2004) Development of a forest habitat network for Wales: linking research with policy. In: Smithers R (ed) Landscape ecology of trees and forests. In: Proceedings of the 12th annual IALE (UK) conference. IALE, Cirencester, p 224-231

Lund HG (2006) Guide for classifying lands for greenhouse gas inventories. J For 6:211-216

Mackey EC, Shewry MC, Tudor GJ (1998) Landcover change in Scotland 1940s to 1980s. The Stationary Office, Edinburgh

Macklin MG, Johnstone E, Lewin J (2005) Pervasive and long-term forcing of Holocene river instability and flooding in Great Britain by centennial-scale climate change. Holocene 15:937-943

Malby AR, Whyatt JD, Timmis R, Wilby RL, Orr HG (2007) Forcing of orographic rainfall and rainshadow processes by climate change: analysis and implications in the English Lake District. Hydrol Process 52:276-291

Malcolm JR, Liu C, Neilson RP, Hansen L, Hannah L (2006) Global warming and extinctions of endemic species from biodiversity hotspots. Conserv Biol 20:538-548

> Manley G (1951) The range of variation of the British climate. Geogr J 117:43-68

McDowell R, Sharpley A, Folmar G (2001) Phosphorus export from an agricultural watershed: linking source and trans- 
port mechanisms. J Environ Qual 30:1587-1595

McEvoy D, Handley JF, Cavan G, Aylen J, Lindley S, McMorrow J, Glynn S (2006) Climate change and the visitor economy: the challenges and opportunities for England's Northwest. Sustainability Northwest, Manchester, and UKCIP, Oxford

McMorrow J, Aylen J, Albertson K, Cavan G, Lindley S, Handley J, Karoni R (2006) Climate change and the visitor economy: moorland fires in the Peak District National Park. Technical Report No. 3, Sustainability North West, Manchester. Available at: www.snw.org.uk/tourism/down research.html

Millennium Ecosystem Assessment (2005) Ecosystems and human well-being: biodiversity synthesis. World Resources Institute, Washington, DC

Miller JD, Adamson JK, Hirst D (2001) Trends in stream water quality in Environmental Change Network upland catchments: the first 5 years. Sci Total Environ 265:27-38

Mills D (ed) (2003) Salmon at the edge. Blackwell, Oxford

Milne R, Brown TAW (1997) Carbon in the vegetation and soils of Great Britain. J Environ Manage 49:413-433

Monk WA, Wood PJ, Hannah DM, Wilson DA, Extence CA, Chadd RP (2006) Flow variability and macroinvertebrate community response within riverine systems. River Res Appl 22:595-615

Monteith DT, Evans C (2005) Recovery from acidification in the UK: evidence from 15 years of acid waters monitoring. Environ Pollut 137:3-13

Monteith DT, Stoddard JL, Evans CD, de Wit HA and others (2007) Dissolved organic carbon trends resulting from changes in atmospheric deposition chemistry in remote surface waters: a regional appraisal of hypotheses. Nature 450:537-540

Moss R, Oswald J, Baines D (2001) Climate change and breeding success: decline of the capercaillie in Scotland. J Anim Ecol 70:47-61

O'Connell PE, Beven K J, Carney JN, Clements RO and others (2004) Review of impacts of rural land use and management on flood generation. Part A: impact study report. Technical Report FD2114), Defra Flood Management Division, London

Orr HG, Carling PA (2006) Hydro climatic and land use changes in the River Lune catchment, North West England: implications for catchment management. River Res Appl 22:239-255

Orr HG, Walsh CL (2006) Incorporating climate change in channel typologies for the Water Framework Directive. Report to the Environment Agency, Bristol

Osborn TJ, Hulme M (2002) Evidence for trends in heavy rainfall events over the United Kingdom. Philos Trans R Soc Lond A 360:1313-1325

Park J, Jones P, Mortimer S, Stabler M, Tiffin R, IJpelaar J, Strange A, Tranter R (2004) The importance of the quality of the environment for economic development and regeneration in rural areas. Report to Defra, Reading University, Reading. Available at: www.defra.gov.uk/rural/research/ env_qual.htm.

Parmesan C, Yohe G (2003) A globally coherent fingerprint of climate change across natural systems. Nature 421:37-42

Pearce-Higgins JW, Yaldon DW, Whittingham MJ (2005) Warmer springs advance the breeding phenology of golden plovers Pluvialis aprocaria and their prey (Tipulidae). Oecologia 143:470-476

Pepin N, Kidd D (2006) Spatial temperature variation in the eastern Pyrenees. Weather 61:300-310

Pepin N, Losleben M (2002) Climate change in the Colorado Rocky Mountains: free air versus surface temperature trends. Int J Climatol 22:311-329
Piper JM, Wilson PB, Weston J, Thompson S, Glasson J (2006) Spatial planning for biodiversity in our changing climate. English Nature Research Reports No. 677, English Nature, Peterborough

Pretty JN, Brett C, Gee D, Hine RE and others (2000) An assessment of the external costs of UK agriculture. Agric Syst 65:113-136

Quinton JN, Catt JA, Wood GA, Steer J (2006) Soil carbon losses by water erosion: experimentation and modelling at field and national scales in the UK. Agric Ecosyst Environ 112:87-102

Rahel FJ, Keleher CJ, Anderson JL (1996) Potential habitat loss and population fragmentation for cold water fish in the North Platte River drainage of the Rocky Mountains: response to climate warming. Limnol Oceanogr 41: 1116-1123

Raper SCB, Braithwaite RJ (2006) Low sea level rise projections from mountain glaciers and icecaps under global warming. Nature 439:311-313

Ratcliffe DA, Thompson DBA (1988) The British uplands: their ecological character and international significance. In: Usher MB, Thompson DBA (eds) Ecological change in the uplands. Blackwell Scientific Publications, London, p 9-36

> Raven PJ, Holmes NTH, Dawson FH, Everard M (1998) Quality assessment using River Habitat Survey data. Aquat Conserv: Mar Freshwat Ecosyst 8:477-499

Robertson AI, Bunn SE, Walker KF, Boon PI (1999) Sources, sinks and transformations of organic carbon in Australian floodplain rivers. Mar Freshw Res 50:813-829

Robson AJ (2002) Evidence for trends in UK flooding. Philos Trans R Soc Lond A 360:1327-1343

Root TL, Schneider SH (2006) Conservation and climate change: the challenges ahead. Conserv Biol 20:706-708

Root TL, Price JT, Hall KR, Schneider SH, Rosenzweig C, Pounds JA (2003) Fingerprints of global warming on animals and plants. Nature 421:57-60

> Roulet N, Moore T (2006) Browning the waters. Nature 444: 283-284

Rounsevell MDA, Ewert F, Reginster I, Leemans R, Carter TR (2005) Future scenarios of European agricultural land use. II. Projecting changes in cropland and grassland. Agric Ecosyst Environ 107:117-135

Rumsby BT, Macklin MG (1994) Channel and floodplain response to recent abrupt climate change: the Tyne Basin, northern England. Earth Surf Process Landf 19:499-515

> Scheffer M, Carpenter S, Foley J, Folke C, Walker B (2001) Catastrophic shifts in ecosystems. Nature 413:591-596

Schindler DW (2001) The cumulative effects of climate warming and other human stresses on Canadian freshwaters in the new millennium. Can J Fish Aquat Sci 58:18-29

Scottish Agricultural College (2002) Agri-environmental employment in Scotland. Commissioned Report F00AA106, Scottish Natural Heritage, Edinburgh. Available at: www.snh.org.uk/pdfs/publications/commissioned_reports/ f00aa106.pdf

Scottish Executive (2004) Scottish Planning Policy SPP7: planning and flooding. Scottish Executive, Edinburgh

Scottish Executive (2007) ECOSSE: estimating carbon in organic soils. Scottish Executive Environment and Rural Affairs Department, Edinburgh. Available at: www. scotland.gov.uk/Publications/2007/03/16170508/0

Sear DA, Newson MD, Brookes A (1995) Sediment-related river maintenance: the role of fluvial geomorphology. Earth Surf Process Landf 20:629-647

SEPA (Scottish Environment Protection Agency) (2006) The state of Scotland's environment 2006. SEPA, Edinburgh. Available at: www.sepa.org.uk/changetomorrowtoday/

Shankman D, Pugh TB (1992) Discharge response to channelization of a coastal plain stream. Wetlands 12:157-162 
Sharpley AN (2000) Agriculture and phosphorus management: the Chesapeake Bay. CRC Press, Boca Raton, FL

Simberloff DS (1998) Flagships, umbrellas, and keystones: Is single-species management passé in the landscape era? Biol Conserv 83:247-257

Simmons IG (2003) The moorlands of England and Wales: an environmental history $8000 \mathrm{BC}$ to AD 2000. Edinburgh University Press, Edinburgh

Smart SM, Robertson JC, Shield EJ, van de Poll HM (2003) Locating eutrophication effects across British vegetation between 1990 and 1998. Global Change Biology 9(12): $1763-1774$

Smit B, Wandel J (2006) Adaptation, adaptive capacity and vulnerability. Glob Environ Change 16:282-292

Smit B, Burton I, Klein R, Street R (1999) The science of adaptation: a framework for assessment. Mitig Adapt Strategies Glob Change 4:199-213

Smith P, Martino D, Cai Z, Gwary D and others (2007a) Policy and technological constraints to implementation of greenhouse gas mitigation options in agriculture. Agric Ecosyst Environ 118:6-28

Smith P, Chapman SJ, Scott WA, Black HJJ and others (2007b) Climate change cannot be entirely responsible for soil carbon loss observed in England and Wales, 19782003. Glob Change Biol 13: 2605-2609

Sowerby A, Emmett BA, Tietema A, Beier C (2008) Contrasting effects of repeated summer drought on soil carbon efflux in hydric and medic heathland soils. Glob Change Biol (in press) doi:10.1111/j.1365-2486.2008.01643.x

Sparks T, Collinson N (2006) The UK phenology networksome highlights from 2005. British Wildlife 17:237-241

Stern N (2006) The economics of climate change: the Stern review. Cambridge University Press, Cambridge

Stott T, Mount N (2004) Plantation forestry impacts on sediment yields and downstream channel dynamics in the UK: a review. Prog Phys Geogr 28:197-240

Stuki EW, Roque O, Schuler M, Perlik M (2004) National report for the study on 'Analysis of mountain areas in the European Union and in the applicant countries'. Report commissioned by the SECO Federal Department of economic affairs, Swiss Federal Institute of Technology, Zurich. Available at: www.seco.admin.ch/imperia/md/content/standort foerderung/regional-undraumordnungspolitik/173.pdf

Sutherland WJ (2006) Predicting the ecological consequences of environmental change: a review of methods. J Appl Ecol 43:599-616

Thomas MF (2001) Landscape sensitivity in time and space: an introduction. CATENA 42:83-98

Thomas CD, Cameron A, Green RE, Bakkenes M and others (2004) Extinction risk from climate change. Nature 427: $145-148$

Tockner K, Pennetzdorfer D, Reiner N, Schiemer F, Ward JV (1999) Hydrological connectivity, and the exchange of organic matter and nutrients in a dynamic river-floodplain system (Danube, Austria). Freshw Biol 41:521-535

Tollan A (2002) Land-use change and floods: What do we need most: research or management? Water Sci Technol 45:183-190

Viner D, Sayer M, Vyarra MC, Hodgson RI (2006) Climate change and the European countryside: impacts on land management and response strategies. CLIO project report, Climate Research Unit, Norwich

Vollenweider RA (1968) Scientific fundamentals of the eutrophication of lakes and flowing waters, with particular reference to nitrogen and phosphorus as factors in eutrophication. Technical Report DAS/CS1/68.27, OECD, Paris

Wade S, Vidal JP (2006) Effect of climate change on river flows and groundwater recharge: rainfall-runoff model-

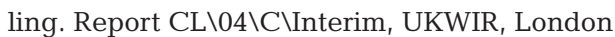

Wade S, Vidal JP, Dabrowski C, Young P, Romanowicz R (2005) Effect of climate change on river flows and groundwater recharge. Trends in UK river flows: 1970-2002.

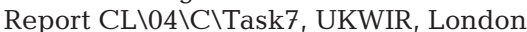

> Wallage ZE, Holden J, Mcdonald AT (2006) Drain blocking: an effective treatment for reducing dissolved carbon loss and water discolouration in a drained peatland. Sci Total Environ 367:811-821

Walmsley CA, Smithers RJ, Berry PM, Harley M, Stevenson MJ, Catchpole R (eds) (2007) MONARCH-Modelling Natural Resource Responses to Climate Change-a synthesis for biodiversity conservation.UKCIP, Oxford

Warburton J, Holden J, Mills AJ (2004) Hydrological controls of surficial mass movements in peat. Earth Sci Rev 67: $139-156$

> Watson A, Pottie J, Duncan D (2004) No Scottish snow patches survive through the summer of 2003. Weather 59:125-126

- Werritty A (2002) Living with uncertainty: climate change, river flows and water resource management in Scotland. Sci Total Environ 294:29-40

- Werritty A, Leys KF (2001) The sensitivity of Scottish rivers and upland valley floors to recent environmental change. CATENA 42:251-273

Wheater HS (2002) Progress in and prospects for fluvial flood modelling. Philos Trans R Soc Lond A 360(1796): 1409-1431

Whitehead PG, Wilby RL, Butterfield D, Wade AJ (2006) Impacts of climate change on nitrogen in a lowland chalk stream: an appraisal of adaptation strategies. Sci Total Environ 365:260-273

Wiesenthal T, Mourelatou A, Petersen JE, Taylor P (2006) How much bioenergy can Europe produce without harming the environment? EEA Report 7:72, European Environment Agency, Copenhagen

Wilby RL (1996) Critical loads' sensitivity to climate change. Environ Conserv 22:363-365

Wilby RL (2006) When and where might climate change be detectable in UK river flows? Geophys Res Lett 33: L19407

Wilby RL, Hedger M, Orr HG (2005) Climate change impacts and adaptation: a science agenda for the Environment Agency of England and Wales. Weather 60:206-211

> Wilby RL, Orr HG, Hedger M, Forrow D, Blackmore M (2006) Risks posed by climate change to delivery of Water Framework Directive objectives. Environ Int 32:1043-1055

Wilby RL, Beven KJ, Reynard NS (2007) Climate change and fluvial flood risk in the UK: More of the same? Hydrol Process 22:2511-2523

Williams JM (ed) (2006) Common standards monitoring for designated sites: first six year report. JNCC, Peterborough

Worrall F, Burt TP (2004) Time series analysis of long term river DOC records. Hydrol Process 18:893-911

Worrall F, Burt TP (2005) Reconstructing long-term records of dissolved $\mathrm{CO}_{2}$. Hydrol Process 19:1791-1806

Worrall F, Burt TP, Sheddon R (2003) Long term records of riverine carbon flux. Biogeochemistry 64:165-178

Worrall F, Burt TP, Adamson J (2004) Can climate change explain increases in DOC flux from upland peat catchments? Sci Total Environ 326:95-112

- Worrall F, Burt T, Adamson J (2006) Long-term changes in hydrological pathways in an upland peat catchment. J Hydrol 321:5-20

Worrall F, Armstrong A, Adamson JK (2007) The effect of burning and sheepgrazing on water table depth and soil water quality in a blanket bog. J Hydrol 339:1-14

Wright RF, Larssen $T$, Camarero L, Cosby BJ and others (2005) Recovery of acidified European surface waters. Environ Sci Technol 39:64A-72A 